\title{
Hydrological (in)stability in Southern Siberia during the Younger Dryas and early Holocene
}

\author{
P. Harding ${ }^{\text {a,b, }}$, E.V. Bezrukova ${ }^{\text {c,d }}$, S.S. Kostrova ${ }^{\text {c, e }}$, J.H. Lacey ${ }^{f}$, M.J. Leng ${ }^{\text {f,g }}$, H. Meyer ${ }^{\text {e }}$ L. \\ A. Pavlova ${ }^{c}$, A. Shchetnikov ${ }^{\text {h,i,j }}$, M.V. Shtenberg ${ }^{k}$, P.E. Tarasov ${ }^{1}$, A.W. Mackay ${ }^{a}$ \\ ${ }^{a}$ Environmental Change Research Centre, Department of Geography, University College London, London WC1E 6BT, UK \\ ${ }^{\mathrm{b}}$ Centre for Quaternary Research, Dept. of Geography, Royal Holloway, TW20 OEX, UK \\ ${ }^{\mathrm{c}}$ Vinogradov Institute of Geochemistry, SB RAS, Irkutsk 664033, Russia \\ ${ }^{\mathrm{d}}$ Irkutsk Scientific Center, SB RAS, Irkutsk 664033, Russia \\ e Alfred Wegener Institute, Helmholtz Centre for Polar and Marine Research, Research Unit Potsdam, Potsdam 14473, Germany \\ ${ }^{\mathrm{f}}$ National Environmental Isotope Facility, British Geological Survey, Keyworth NG12 5GG, UK \\ ${ }^{g}$ Centre for Environmental Geochemistry, School of Biosciences, University of Nottingham, LE12 5RD, UK \\ ${ }^{\mathrm{h}}$ Institute of the Earth's Crust, SB RAS, Irkutsk 664033, Russia \\ i Irkutsk State University, 2 Chkalov St., Irkutsk 664003, Russia \\ ${ }^{\mathrm{j}}$ Geological Institute, Russian Academy of Sciences, Pyzhevsky lane 7, 119017 Moscow, Russia \\ ${ }^{\mathrm{k}}$ Institute of Mineralogy, UB RAS, Miass 456317, Russia \\ ${ }^{1}$ Institute of Geological Sciences, Palaeontology, Freie Universitaet Berlin, Berlin 12249, Germany
}

\section{A R T I C L E I N F O}

\section{Keywords:}

LGIT

Siberia

Paleoclimate

Paleohydrology

Stable-isotopes

Diatoms

\begin{abstract}
A B S T R A C T
Southern Siberia is currently undergoing rapid warming, inducing changes in vegetation, loss of permafrost, and impacts on the hydrodynamics of lakes and rivers. Lake sediments are key archives of environmental change and contain a record of ecosystem variability, as well as providing proxy indicators of wider environmental and climatic change. Investigating how hydrological systems have responded to past shifts in climate can provide essential context for better understanding future ecosystem changes in Siberia. Oxygen isotope ratios within lacustrine records provide fundamental information on past variability in hydrological systems. Here we present a new oxygen isotope record from diatom silica $\left(\delta^{18} \mathrm{O}_{\text {diatom }}\right)$ at Lake Baunt $\left(55^{\circ} 11^{\prime} 15^{\prime \prime} \mathrm{N}, 113^{\circ} 01,45^{\prime \prime} \mathrm{E}\right)$, in the southern part of eastern Siberia, and consider how the site has responded to climate changes between the Younger Dryas and Early to Mid Holocene (ca. 12.4 to $6.2 \mathrm{ka}$ cal BP). Excursions in $\delta^{18} \mathrm{O}_{\text {diatom }}$ are influenced by air temperature and the seasonality, quantity, and source of atmospheric precipitation. These variables are a function of the strength of the Siberian High, which controls temperature, the proportion and quantity of winter versus summer precipitation, and the relative dominance of Atlantic versus Pacific air masses. A regional comparison with other Siberian $\delta^{18} \mathrm{O}_{\text {diatom }}$ records, from lakes Baikal and Kotokel, suggests that $\delta^{18} \mathrm{O}_{\text {diatom }}$ variations in southern Siberia reflect increased continentality during the Younger Dryas, delayed Early Holocene warming in the region, and substantial climate instability between $\sim 10.5$ to $\sim 8.2 \mathrm{ka}$ cal BP. Unstable conditions during the Early Holocene thermal optimum most likely reflect localised changes from glacial melting. Taking the profiles from three very different lakes together, highlight the influence of site specific factors on the individual records, and how one site is not indicative of the region as a whole. Overall, the study documents how sensitive this important region is to both internal and external forcing.
\end{abstract}

\section{Introduction}

Anthropogenic climate change is having a significant impact on hydrology and ecosystems globally. Reconstructing past palaeohydrological responses to climate change is fundamental for assessing potential future responses to climate change (Swann et al., 2018). Southern Siberia is currently undergoing climate warming at a rate considerably higher than the global average (Tingley and Huybers, 2013). The effects of this are significant, especially the reduction in hemiboreal forests (Deluca and Boisvenue, 2012) through changes to

\footnotetext{
* Corresponding author at: Centre for Quaternary Research, Dept. of Geography, Royal Holloway, TW20 0EX, UK.

E-mail address: poppy.harding@rhul.ac.uk (P. Harding).
} 
wildfire frequency (Tchebakova et al., 2011), increased melting of permafrost (Romanovsky et al., 2010), and changes to seasonally-ice covered lacustrine ecosystems (Moore et al., 2009; Tchebakova et al., 2009; Tchebakova et al., 2011). In some regions, the drivers of past climatic events have been well studied (Bond, 1997; Bond et al., 2001; Hoek and Bos, 2007; Teller et al., 2002; Wanner et al., 2011), and their impacts on hydrology and ecosystems are well defined (Brauer et al., 2008; Fletcher et al., 2010; Lane et al., 2013; Rach et al., 2014). However, other critical regions, such as continental ecotones, are relatively understudied. For example, the majority of studies in southern Siberia are focussed on the Lake Baikal ecosystem (Katsuta et al., 2018; Mackay et al., 2013a; Mackay et al., 2011; Mackay et al., 2005; Morley et al., 2005; Prokopenko et al., 2002; Prokopenko et al., 1999; Prokopenko and Williams, 2004; Rioual and Mackay, 2005; Swann et al., 2018; Tarasov et al., 2007; Williams et al., 1997). Further research is, thus, essential to investigate hydrological changes outside of Lake Baikal's immediate catchment.

Globally, the transition to the current interglacial sees a number of important climatic events, with Younger Dryas cooling marking the last stage of the glacial from $\sim 13 \mathrm{ka}$ cal $\mathrm{BP}$, and rapid Holocene warming from $\sim 11.7$ ka cal BP (Blockley et al., 2012; Rasmussen et al., 2014), both influencing atmospheric regimes (Steffensen et al., 2008; Wang et al., 2001). The Early Holocene also features abrupt climatic events at 11.4, 11.1, 9.3 and 8.2 ka cal BP (Blockley et al., 2018; Dykoski et al., 2005; Heiri et al., 2004; Hoek and Bos, 2007; Rasmussen et al., 2014; Zhang et al., 2018), thought to be linked to freshwater outbursts, reducing thermohaline circulation (THC) in the North Atlantic (Barber et al., 1999; Rohling and Pälike, 2005; Teller et al., 2002), solar minima (Bond et al., 2001; Dykoski et al., 2005), and volcanic eruptions (Anchukaitis et al., 2010; Cole-Dai et al., 2013; Sigl et al., 2015). This period provides important context for future climate changes, as much of the temperature variability is within the range predicted for the next 100-200 years $\left(2-4^{\circ} \mathrm{C}\right)$ (Collins et al., 2013). Moreover, destabilisation of ice sheets, THC variability and changing solar activity are also important elements of future climate scenarios (Collins et al., 2013).

The Younger Dryas is documented across the Northern Hemisphere (Brauer et al., 2008; Brooks et al., 2012; Coope et al., 1998; Heiri and Millet, 2005), with cooling thought to be driven by changes in Atlantic meridional overturning circulation (Lane et al., 2013), which are then propagated to the atmosphere (Bakke et al., 2009). The Transbaikal region of southern Siberia experienced strong seasonality during the Younger Dryas due to high obliquity, inducing cold winters (Bush, 2005). High $\mathrm{K}+$ concentrations in the GISP2 ice core during the latter stages of the Younger Dryas suggest that a strong Siberian High dominated winter climates (Mayewski et al., 2004; Tarasov et al., 2009). A strong Siberian High drives a stronger East Asian Winter Monsoon, through a larger pressure gradient between the Siberian High and Aleutian Low (Tubi and Dayan, 2013), resulting in weaker East Asian Summer Monsoons. The latter is reflected in higher isotope values from Chinese speleothems in Hulu (Wang et al., 2001), Dongge (Dykoski et al., 2005) and Sanbao (Dong et al., 2010) caves, and cold reconstructed temperatures in Lake Suigetsu, Japan (Schlolaut et al., 2017). During the Early Holocene, maximum summer insolation values occurred (Bush, 2005), leading to the Holocene Thermal Maximum at $\sim 10.0$ and $6.0 \mathrm{ka}$ cal BP (Liu et al., 2014). At higher latitudes, particularly away from large ice sheets, a shorter thermal maximum occurred between $\sim 10.0$ and $8.0 \mathrm{ka}$ cal BP (Jansen et al., 2007; Renssen et al., 2012), coupled with strong seasonality (Biskaborn et al., 2016; Bush, 2005).

The isotopes of diatom silica are widely recognised as proxies for environmental change, such as the use of the oxygen isotope ratios to reconstruct palaeohydrology (Leng and Barker, 2006; van Hardenbroek et al., 2018). $\delta^{18} \mathrm{O}$ is influenced by changes in external environmental and climatic factors, including the quantity or source of precipitation, atmospheric temperature variability, and evaporation regimes. $\delta^{18} \mathrm{O}_{\text {diatom }}$ reconstructions are available for key southern Siberian sites, including Lake Baikal (Mackay et al., 2013b; Mackay et al., 2011) and Lake Kotokel, located to the east of the Baikal central basin (Kostrova et al., 2013b, 2014, 2016). In Lake Baikal, $\delta^{18} \mathrm{O}_{\text {diatom }}$ variability has been linked to factors including the relative proportion of southern versus northern rivers feeding the lake, due to its enormous catchment (Mackay et al., 2011), and at Lake Kotokel to the interplay of evaporation and the $\delta^{18} \mathrm{O}$ of precipitation, which is linked to air temperature and atmospheric circulation (Kostrova et al., 2013b, 2014, 2016).

This study aims to increase the understanding of palaeohydrological changes that have occurred at the sensitive discontinuous-continuous permafrost boundary in Siberia. We present new $\delta^{18} \mathrm{O}_{\text {diatom }}$ data from a sediment core from Lake Baunt (below), one of the first analyses of lake records with a localised catchment spanning the Younger Dryas to Mid Holocene in the northern regions of southern Siberia. We combine our $\delta^{18} \mathrm{O}_{\text {diatom }}$ record with existing data from Lakes Baikal and Kotokel, and examine regional palaeohydrology, and consider local and extrinsic mechanisms that may be driving palaeohydrological variability (Williams et al., 2011).

\subsection{Study site}

Lake Baunt $\left(55^{\circ} 11^{\prime} 15^{\prime \prime} \mathrm{N}, 113^{\circ} 01^{\prime} 45^{\prime \prime} \mathrm{E}\right)$ is a tectonic lake (Bezrukova et al., 2017) in the Transbaikal mountains of southern Siberia, $200 \mathrm{~km}$ to the east of Lake Baikal's northern basin (Fig. 1) and is one of the larger lakes in the Tsipikan-Baunt lake district (Shchetnikov, 2007; Yakhnenko et al., 2008). Located at $\sim 1050 \mathrm{~m}$ a.s.l., Baunt has a surface area of 111 $\mathrm{km}^{2}$ (19 km length on a SW-NE elongation and $9 \mathrm{~km}$ width), with an average depth of $17 \mathrm{~m}$ and maximum depth of $33 \mathrm{~m}$ (Krainov et al., 2017). The catchment predominantly lies to the south, east, and west (Krainov et al., 2017), and is bounded by the Ikat and Tsipikan highlands (Solotchin et al., 2015) (Fig. 1). Glaciation in this region is limited to the Kodar range of the Transbaikal mountains (Stokes et al., 2013), and has receded recently due to anthropogenic warming, while extensive mountain glacier coverage existed during the Last Glacial (Margold et al., 2016; Martin and Jansson, 2011; Stokes et al., 2013). Baunt receives water from the Verkhnyaya (Upper) Tsipa and Tsipikan rivers (Krainov et al., 2017), and discharges into the Nizhnyaya (Lower) Tsipa River (Ufimtsev et al., 2009) (Fig. 1). It is currently oligotrophic (surface water pH 7-7.2 (Kozhov, 1950)) and undergoes thermal stratification during the summer, but is frozen for $\sim 8$ months (October-May) (Alpat'ev et al., 1976).

The regional geology is predominantly the Barguzin and Vitimkan igneous granitic complexes (part of the Angara-Vitim batholith) (Nenakhov and Nikitin, 2007; Rytsk et al., 2007; Tsygankov et al., 2007). In the lake basin, Neogene-Quaternary sediments including sands, clays and gravels dominate (Bezrukova et al., 2017; Krainov et al., 2017; Shchetnikov, 2007), while Holocene sediments include lacustrine, fluvial and peat deposits (Bezrukova et al., 2017). No carbonate rocks are found within the catchment (Ryabenko et al., 1964), which sits in taiga forest, dominated by Larix gmelinii (Larch) and Pinus sylvestris (Scots Pine). Mountain shrubs, grass and moss tundra occupy higher altitudes (Anekhonov, 1995; Müller et al., 2014).

Regional climate is dominated by the Siberian High anticyclone, with winter pressures reaching $\sim 1030 \mathrm{mb}$ (Tubi and Dayan, 2013), but in summer, when it is inactive, pressures drop to $\sim 1005 \mathrm{mb}$. For the period between 1961 and 1990 CE (common era), averaged mean air temperatures at Baunt, corrected for elevation, are $+15.7^{\circ} \mathrm{C}$ (July) and $-28.4^{\circ} \mathrm{C}$ (January) (Leemans and Cramer, 1991). Average annual precipitation is $\sim 400 \mathrm{~mm}$ (Leemans and Cramer, 1991), with the highest levels in summer (Huhne and Slingo, 2011). Precipitation is generally considered to be North Atlantic sourced recycled summertime rainfall, transported by the westerlies (Park et al., 2014; Tubi and Dayan, 2013), with a small proportion from wintertime snowfall (Huhne and Slingo, 2011). However, recent work indicates the region is influenced by the Atlantic westerlies, the East Asian Monsoon, and intrusions of Arctic air (Kostrova et al., 2020; Osipova and Osipov, 2019). The relative 




Fig. 1. (A) Schematic Map of Asia highlighting the position of Lakes Baunt, Kotokel and Baikal. Lake Baikal's catchment area is shown. (B) Closer image of the Lake Baikal region, showing Lake Baunt alongside major rivers in the region. (C) Close image of Lake Baunt highlighting basin topography and the regional topography. Drill location of the BNT14 core is shown alongside locations where water samples were taken from Lake Baunt and surrounding rivers and lakes. River inflows and outflow are shown with directional arrows. (D) Core litho-stratigraphy for BNT14 summarised from Krainov et al. (2017).

proportion of these sources varies across the year, with winter months and transitional periods (March-April-May and September-OctoberNovember) dominated by westerly precipitation (Kostrova et al., 2020; Osipova and Osipov, 2019), while during summer, inflows from the south-west and south-east increase (Osipova and Osipov, 2019). Variations in the contribution from these sources change across the Transbaikal mountains, with southern regions being more heavily influenced by southerly sources (Osipova and Osipov, 2019).

\section{Methodology}

\subsection{Core collection and lithology}

The BNT14 core $\left(55^{\circ} 11^{\prime} 15^{\prime \prime} \mathrm{N}, 113^{\circ} 01^{\prime} 45^{\prime \prime} \mathrm{E}\right.$; water depth $33 \mathrm{~m}$; Fig. 1C) was collected in March 2014, while the lake was frozen (maximum ice thickness of $\sim 2 \mathrm{~m}$ with limited movements) using a UWITEC gravity corer (Krainov et al., 2017), at the site identified to have the most uniform sedimentation rates. The UWITEC system used hammer action with inner $63 \mathrm{~mm}$ PVC liners to extract the $13.66 \mathrm{~m}$ core in 8 liners, over 3 days, with a 95\% recovery rate (Krainov et al., 2017). The litho-stratigraphy consists of silty clay at the base $(1366-1170 \mathrm{~cm})$, followed by a change to silty clay with abundant diatoms (1170-620 $\mathrm{cm}$ ). A short section of diatomaceous ooze occurs between 620 and 580 $\mathrm{cm}$, followed by a return to silty clay with diatoms. From $540 \mathrm{~cm}$ there is a switch to diatomaceous ooze, which continues to the core top. For full description see Krainov et al. (2017) (Fig. 1D).

\subsection{Chronology construction}

The Lake Baunt chronology is a refined version of the age model developed by (Krainov et al., 2018; Krainov et al., 2017) and is based on 15 radiocarbon dates of bulk sediments (Table 1 ), coupled with ${ }^{210} \mathrm{~Pb}$ analyses, which attempt to constrain the upper-most sections (supplementary information).
Table 1

AMS radiocarbon dates from the BNT14 core. Dates were calibrated using IntCal20 (Reimer et al., 2020) in OxCal 4.4.

\begin{tabular}{llll}
\hline Sample code & Sample depth $(\mathrm{cm})$ & 14C age & IntCal20 calibrated range \\
\hline Poz-BNT14-52 & 52 & $5590 \pm 35$ & $6439-6295$ \\
UBA-32755 & 97.5 & $5049 \pm 40$ & $6609-6302$ \\
Poz- BNT-200 & 200 & $5775 \pm 30$ & $7452-6451$ \\
Poz- BNT-400 & 400 & $9000 \pm 50$ & $10,340-9891$ \\
UBA-32756 & 497.5 & $11,489 \pm 60$ & $13,497-12,863$ \\
Poz- BNT-600 & 600 & $11,620 \pm 50$ & $13,601-13,368$ \\
Poz-BNT-692 & 691 & $14,090 \pm 80$ & $17,403-16,885$ \\
Poz-BNT-800 & 800 & $14,930 \pm 70$ & $18,621-18,071$ \\
Poz-BNT-950 & 950 & $18,220 \pm 80$ & $22,385-21,900$ \\
Poz-BNT-1110 & 1110 & $18,850 \pm 120$ & $24,465-22,438$ \\
Poz-BNT-1150 & 1150 & $20,680 \pm 140$ & $25,328-24,329$ \\
Poz-BNT-1172 & 1172 & $21,670 \pm 140$ & $26,195-25,703$ \\
Poz-BNT-1195 & 1195 & $21,720 \pm 140$ & $26,310-25,820$ \\
Poz-BNT-1277 & 1277 & $24,760 \pm 190$ & $29,315-28,565$ \\
Poz-BNT-1350 & 1350 & $25,350 \pm 180$ & $30,000-29,215$ \\
\hline
\end{tabular}

The ${ }^{210} \mathrm{~Pb}$ profile was produced using four air dried samples from the upper $10 \mathrm{~cm}$ of the BNT14 core, which were analysed by direct gamma assay for ${ }^{210} \mathrm{~Pb},{ }^{137} \mathrm{Cs},{ }^{226} \mathrm{Ra}$ and ${ }^{241} \mathrm{Am}$ using an ORTEC HPGe GWL series well-type coaxial low background intrinsic germanium detector, at the Environmental Radiometric Facility at University College London. ${ }^{210} \mathrm{~Pb}$ was determined from gamma emission at $46.5 \mathrm{keV}$, while ${ }^{226} \mathrm{Ra}$ was determined by the $295 \mathrm{keV}$ and $352 \mathrm{keV}$ gamma rays, re emitted by its daughter isotope ${ }^{214} \mathrm{~Pb}$, following 3 weeks storage in sealed containers, allowing radioactive equilibration (Appleby et al., 1986). ${ }^{137} \mathrm{Cs}$ and ${ }^{241} \mathrm{Am}$ were determined by their emissions at $662 \mathrm{keV}$ and $59.5 \mathrm{keV}$ (Appleby et al., 1986). Detector efficiencies were measured using calibrated sourced and sediment samples of known activity, with corrections being made for the effect of self-absorption of low energy gamma rays within the sample (Appleby, 2002).

The chronological information (Table 1) has undergone Bayesian age 
modelling in OxCal 4.4 to produce a $P_{-}$Sequence depositional model (Bronk Ramsey, 2008; Bronk Ramsey, 2009a; Bronk Ramsey, 2009b), within which, radiocarbon dates were calibrated using the IntCal20 curve (Reimer et al., 2020). The model incorporates automatic outlier detection using the general model (Bronk Ramsey, 2009b) with interpolation between dates allowing for sedimentological changes between dated points (Bronk Ramsey and Lee, 2013). A boundary, which is a Bayesian function to recognise differences between sedimentary or chronological units within a sequence, has been incorporated into the model during a period of sediment source change, identified in the core lithostratigraphy (see Krainov et al., 2018; Krainov et al., 2017).

To facilitate comparison between regional lake records, chronological records from lakes Baikal (composite chronology for cores CONO1605-5 and CON01-605-3 from the Vydrino Shoulder) and Kotokel (core KTK2) were re-modelled using IntCal20 (Reimer et al., 2020), as previous studies used different calibration curves, IntCal09 and CalPal07_Hulu respectively (Bezrukova et al., 2010; Mackay et al., 2011), with different underlying data and statistical treatment of the calibration information (e.g. Reimer et al., 2009; Weninger and Jöris, 2008). Models were produced following the same method as described above for Lake Baunt. Furthermore, in this study, the Lake Kotokel age model does not include dates transferred from the Lake Sihailongwan record $\left(42^{\circ} 17^{\prime} \mathrm{N}, 126^{\circ} 36^{\prime} \mathrm{E}\right.$ ) (Bezrukova et al., 2010; Stebich et al., 2009) due to the large distance between the two sites, which could introduce monsoonal influences into the regional comparison. The approach of using only locally derived chronological information is undertaken to ensure the three records can be compared independently to each other, to build up a picture of regional palaeohydrological change.

\subsection{Diatom analyses}

Diatom composition analyses were undertaken across the BNT14 core. Samples were prepared following the digestion procedure of Battarbee et al. (2001) (supplementary information). Diatom analyses were converted to relative proportions (\%), concentrations and diatom fluxes (supplementary information). Diatom dissolution was quantified for the dominant taxa, with individual frustules being classified into 1 of 4 stages: (1) pristine, (2) little dissolution, (3) very dissolved, and (4) almost unrecognisable. Dissolution stages were converted to a dissolution $F_{-}$index (Ryves et al., 2001: Flower and Ryves, 2009), using the observations above to determine a ratio of pristine valves against total counts, expressed as:

$F i=\sum_{j}^{m} n i j / \sum_{j}^{m} N$

where $F_{i}$ is the $F_{-}$index for sample $\mathrm{i}, \mathrm{n}$ is the sum of the pristine valves for species $\mathrm{j}$ in the sample, and $\mathrm{N}$ is the sum of the total number of valves in the same sample.

\subsection{Isotope analyses}

\subsubsection{Water samples}

In 2014 and 2016, water samples were collected from Lake Baunt and its fluvial inflows, and a small nearby lake. Samples were collected in spring (23-Mar-2014; $n=3$, 27-Mar-2016; $n=1$, 30-Mar-2016; $n=$ 2 ), while the lake was frozen, and during summer, post ice melt (21-Aug2014; $n=6$ ). Hydrogen and oxygen isotope analysis was conducted at the Isotope Laboratory (AWI Potsdam) with a Finnigan MAT Delta-S mass spectrometer using equilibration techniques. Internal $1 \sigma$ errors was better than $\pm 0.8 \%$ for $\delta \mathrm{D}$ and $\pm 0.1 \%$ for $\delta^{18} \mathrm{O}$ (Meyer et al., 2000).

\subsection{2. $\delta^{18} \mathrm{O}_{\text {diatom }}$ analyses}

In total, 59 cleaned samples were chosen from the BNT14 core to cover the transition from the Late Pleistocene and the period of instability documented in the Early Holocene (Blockley et al., 2018; Rasmussen et al., 2014). The samples were purified prior to analysis following published procedures (e.g. Brewer et al., 2008; Leng and Marshall, 2004), to exclude other oxygen bearing components (Morley et al., 2004; van Hardenbroek et al., 2018). Cleaning of the Lake Baunt samples followed Morley et al. (2004). Primarily, samples underwent a step-wise removal of organic matter using hydrogen peroxide $\left(\mathrm{H}_{2} \mathrm{O}_{2}\right)$ and hydrochloric acid $(\mathrm{HCl})$, before being sieved over a $5 \mu \mathrm{m}$ mesh to remove clay particles. After this, samples underwent a three-stage heavy liquid separation using sodium polytungstate $\left(3 \mathrm{Na}_{2} \mathrm{WO}_{4} \cdot 9 \mathrm{WO}_{3} \cdot\right.$ $\mathrm{H}_{2} \mathrm{O}$ ). Finally samples were cleaned with a nitric/perchloric acid mixture $\left(\mathrm{HNO}_{3}: \mathrm{HClO}_{4}\right)$ and dried (Morley et al., 2004).

Sample purity was assessed using scanning electron microscopy (SEM) (Earth Sciences Department, University College London) and electron microprobe X-ray analysis (EMPA; Reed, 2005) with a microprobe JXA-8200 (JEOL Ltd., Japan) at the Shared-Use Analytical Centre of the IGC SB RAS, to estimate the remaining contaminants, particularly silt quantities, prior to analysis, to allow them to be used for the massbalance correction. For EMPA, less than $1 \mathrm{mg}$ of purified diatom material was placed on carbon-tabs mounted on duralumin substrate, and carbon coated. Analytical spectra were registered and processed automatically by the EDS Semi-Quantitative Analysis software of the energydispersive spectrometer EX-84055MU (JEOL Ltd., Japan). Quantitative analysis was performed using the standardless procedure (all detectable elements displayed as oxides normalised to $100 \%$ weight); with results expressed as weight percentages (Pavlova et al., 2014).

The oxygen isotope analysis was undertaken at the National Environmental Isotope Facility, British Geological Survey, Keyworth, UK. Samples were prepared for analysis using a step-wise fluorination method (see Leng and Sloane (2008)), where, firstly, samples were 'outgassed' (dehydrated) at room temperature in nickel reaction vessels to remove loosely bound water. Secondly, samples underwent prefluorination, involving a stoichiometric deficiency of the reagent (bromine pentafluoride, $\mathrm{BrF}_{5}$ ) at $250^{\circ} \mathrm{C}$ (Leng and Sloane, 2008), to remove loosely bound water and the hydroxyl layer. This is necessary as this outer hydrous layer is freely exchangeable and does not reflect the isotopic composition of the frustule at the time of burial (Leng and Barker, 2006). Finally, the samples were fully reacted at $500^{\circ} \mathrm{C}$ for $16 \mathrm{~h}$ in an excess of reagent, and the liberated oxygen is separated from waste products using liquid nitrogen, purified using two additional waste traps cooled using liquid nitrogen, and converted to $\mathrm{CO}_{2}$ by exposure to a graphite rod at $\sim 650^{\circ} \mathrm{C}$ (Leng and Sloane, 2008). Once converted, the gas yield was calculated using a calibrated capacitance manometer and the $\mathrm{CO}_{2}$ is collected under liquid nitrogen for analysis. The $\mathrm{CO}_{2}$ produced was analysed using a Finnegan MAT253 dual inlet isotope ratio mass spectrometer. Isotope results are reported in delta $(\delta)$ notation in per mille $(\%)$ and were calibrated to the VSMOW scale using a laboratory reference material of known $\delta^{18} \mathrm{O}(\mathrm{BFC}=+28.9 \%$ VSMOW) relative to the international standard NBS 28. Analytical reproducibility of $\mathrm{BFC}$ for this dataset was $\pm 0.2 \%$.

Despite the intensive cleaning process, some samples contained small levels of contaminants (average of around 6\% contaminant), particularly due to their ability to become electro-statically charged to the diatom frustules (Brewer et al., 2008). To compensate for contaminants potentially affecting the Lake Baunt $\delta^{18} \mathrm{O}_{\text {diatom }}$ record, a mass 
balance correction was applied to the original data, following Swann and Leng (2009). Initially the percentage silt was established (Eq. (2)):

$\%$ Silt Contamination $=($ sample $\mathrm{Al} /$ silt Al $) * 100$

where sample $\mathrm{Al}$ is the EDS-measured $\mathrm{Al}_{2} \mathrm{O}_{3}$ and silt $\mathrm{Al}$ is the average $\mathrm{Al}_{2} \mathrm{O}_{3}$ for terrigenous samples during EDS analysis. Once this was established, a mass balance correction was applied (Eq. (3)).

\section{Results}

\subsection{Age model}

The full age model for Baunt (Fig. 2) only has minor changes from Krainov et al. (2017, 2018) in most places, with the addition of new dating information (additional radiocarbon dates and ${ }^{210} \mathrm{~Pb}$ data). The

$\delta^{18} \mathrm{O}_{\text {corrected }}=\left(\delta^{18} \mathrm{O}_{\text {measured }}-(\%\right.$ Silt Contamination $\left.\left./ 100)\right) * \delta^{18} \mathrm{O}_{\text {contamination }}\right) /(\%$ purity $/ 100)$

where $\delta^{18} \mathrm{O}_{\text {corrected }}$ is the measured value after it has been corrected for contaminants, $\delta^{18} \mathrm{O}_{\text {measured is }}$ the original measured value, \%Silt Contamination is the percentage of the known contaminant $\left(\mathrm{Al}_{2} \mathrm{O}_{3}\right)$, established from EDS measurements, while \%purity is the percentage of diatom material, established by geochemical methods (Swann and Leng, 2009). Silt samples were obtained by dissolving diatoms from 4 samples in $\mathrm{NaOH}$ and retaining the residues that included material in the size fractions between $\sim 5-63 \mu \mathrm{m}$. These end members were used to create a signal end member $\delta^{18} \mathrm{O}_{\text {silt }}$ value of $+10.34 \%$, (Swann and Patwardhan, 2011).

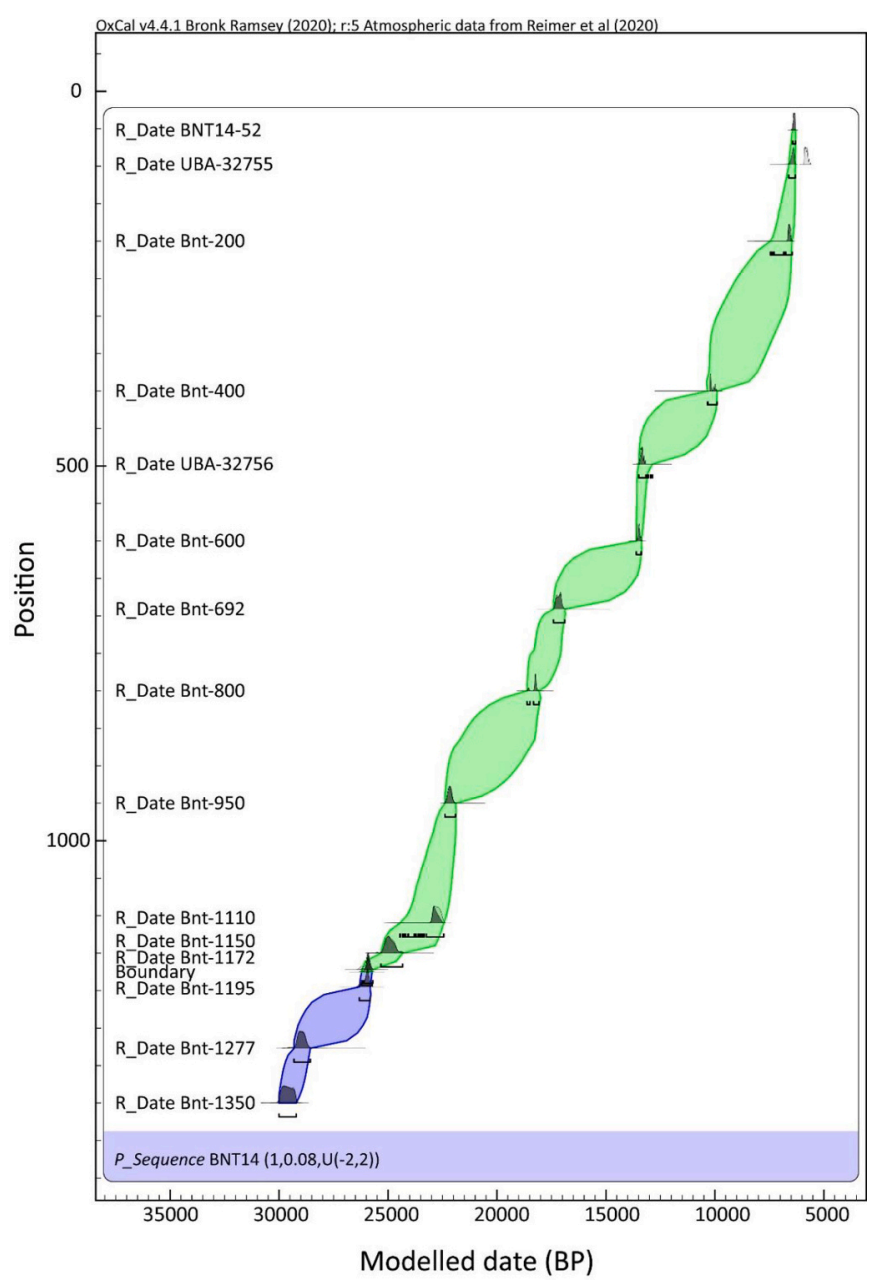

Fig. 2. Bayesian $P_{-}$sequence depositional Age model for Lake Baunt incorporating $15{ }^{14} \mathrm{C}$ dates calibrated using IntCal20 (Reimer et al., 2020), and modelled in OxCal 4.4. biggest differences include that outlier detection has down-weighted one new date, UBA-32755, as a potential outlier, and that the top of the core is now placed around $\sim 6.2 \mathrm{ka}$ cal BP based on new radiocarbon dates, supported by the ${ }^{210} \mathrm{~Pb}$ profile, which demonstrated BNT14 had little unsupported ${ }^{210} \mathrm{~Pb}$ activity, and additionally, artificial fallout radionuclides for ${ }^{137} \mathrm{Cs}$ and ${ }^{241} \mathrm{Am}$, were not identified (supplementary information). This indicates BNT14 does not contain sediments deposited during the past $100-150$ years, and alongside the radiocarbon evidence, suggests that there is a potential hiatus from $\sim 6 \mathrm{ka}$ cal BP, or that the upper section of BNT14 was lost during coring, due to difficult conditions. A rapid rise in sedimentation rate between 600 and $500 \mathrm{~cm}$, is indicative of changes occurring within the lake, which are documented as variations in the lithostratigraphy (Fig. 1D). These highlight a shift to diatomaceous ooze between 620 and $580 \mathrm{~cm}$, followed by a return to silty clay with diatoms at $580 \mathrm{~cm}$ and a switch back to diatomaceous ooze from $540 \mathrm{~cm}$, and therefore, these sedimentation rate variations are linked to periods of increased diatom productivity within the lake, increasing the quantity of diatoms persevered in the sediments, alongside increased organic materials from the wider landscape following afforestation in the late-glacial interstadial (Tarasov et al., 2007, 2009).

The updated age model for Lake Baikal is consistent with the previous age model for the majority of the Holocene (Mackay et al., 2011) (supplementary information), however, earliest Holocene and Younger Dryas sections are now inferred to be slightly older (by $\sim 100-150$ years), but still within the errors on the two chronologies. This is due to the close similarity between the IntCal09 and IntCal20 radiocarbon calibration curves for the Holocene period, as both curves are based on tree ring data sets (Reimer et al., 2009, 2020). This is similar for Lake Kotokel, where most of the updated model is similar to that of Bezrukova et al. (2010) (supplementary information), again linked to the use of tree rings for the upper sections of the calibration curve (Weninger and Jöris, 2008). However, in the section of the core between $\sim 11.6$ and $\sim 7.0 \mathrm{ka}$ cal BP the two models differ, with the largest variation seen at $424 \mathrm{~cm}$, with a difference of $\sim 1000$ years $(\sim 10.6 \mathrm{ka}$ cal BP in the original chronology and $\sim 9.5 \mathrm{ka}$ cal BP in the updated chronology) (Bezrukova et al., 2010). These differences are explained by the different tuning approaches taken between the two age models, with the published Bezrukova et al. (2010) model having a shift in the modelled sedimentation rates for Kotokel, through the addition of the transferred age of $\sim 10.6 \mathrm{ka}$ cal BP, based on dating and pollen information from Lake Sihailongwan $\left(42^{\circ} 17^{\prime} \mathrm{N}, 126^{\circ} 36^{\prime} \mathrm{E}\right)$ (Bezrukova et al., 2010; Stebich et al., 2009), while the revised model used here has linear sedimentation through this section of the core. As discussed above, in this study, only local dating information has been used in the revised age model, so that we can robustly investigate regional palaeohydrology. The oxygen isotope curves for lakes Baikal and Kotokel are plotted on both the previously published, and revised age models for clarity (Section 4).

\subsection{The isotope composition of modern waters}

The average $\delta^{18} \mathrm{O}$ value from Lake Baunt waters is $-16.0 \%$, with 


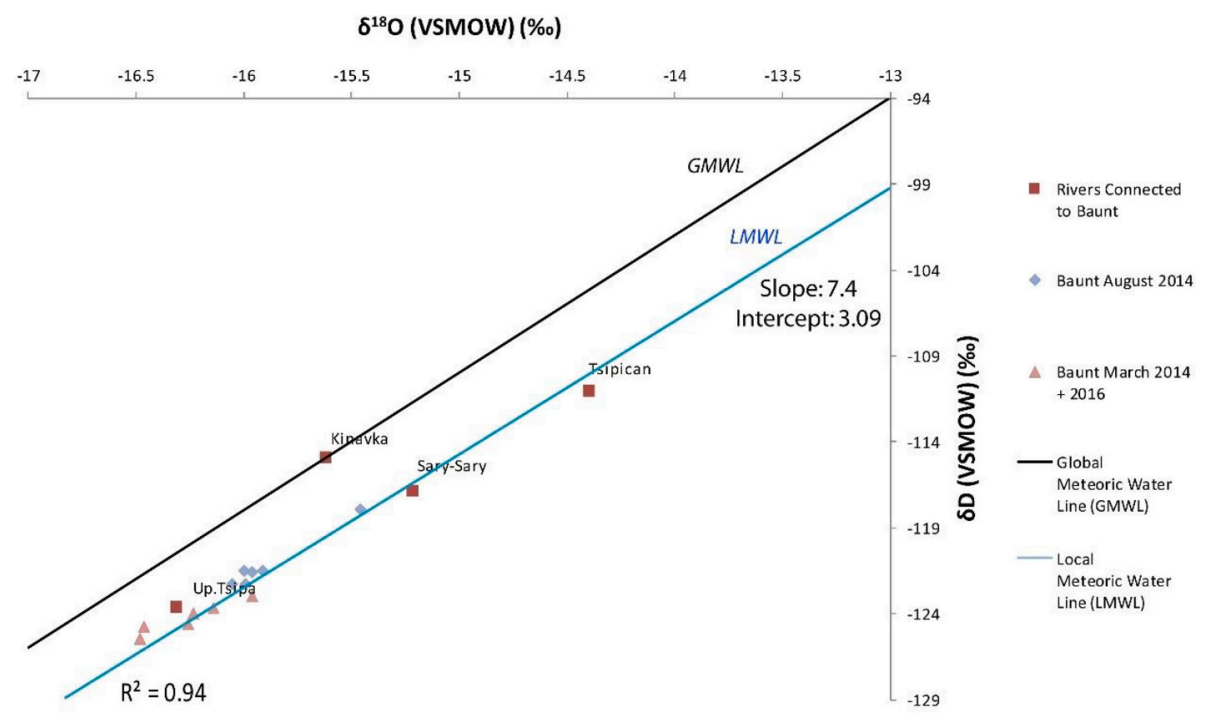

Fig. 3. $\delta^{18} \mathrm{O}-\delta \mathrm{D}$ diagram for the Lake Baunt and nearby water sources against the Global Meteoric Water Line (GMWL).

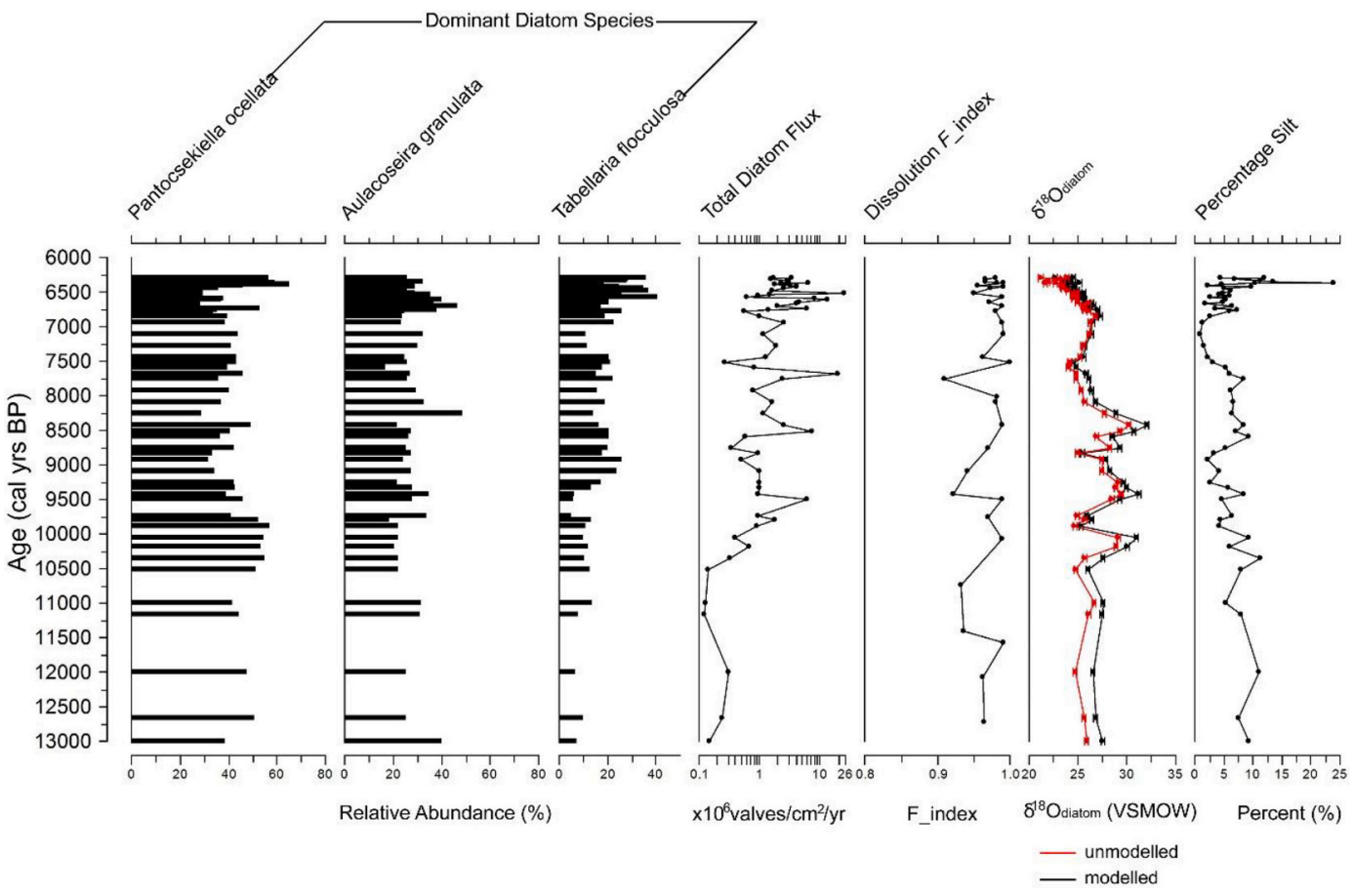

Fig. 4. Summary diatom data showing percentage abundance of the three-dominant species against the Total Diatom Flux (shown on a logarithmic scale), with Dissolution $F_{-}$index scores, alongside the unmodelled and modelled (corrected) $\delta^{18} \mathrm{O}_{\text {diatom }}$ and the percentage silt. Plotted in C2 (Juggins, 2016).

slightly higher average values during the summer $(-15.9 \%)$ than under ice $(-16.3 \%)$. Fig. 3 shows that although average $\delta^{18} \mathrm{O}$ values are similar, there is a small seasonal variation (Fig. 3). Rivers flowing into Baunt have a range of $\delta^{18} \mathrm{O}$ between $-14.49 \%$ and $-16.31 \%$, with greatest similarity seen between the Upper Tsipa river and Baunt. River water temperatures vary substantially, from $5^{\circ} \mathrm{C}$ to $19.6^{\circ} \mathrm{C}$, despite only being taken over 3 days during the summer period (August). All the data lie on the local meteoric water line, except one river.

\section{3. $\delta^{18} O_{\text {diatom }}$ record}

Samples have undergone a mass balance correction (Section 2.4.2) to compensate for any remaining contaminants and hereafter, all $\delta^{18} \mathrm{O}_{\text {dia- }}$ tom values refer to the corrected $\delta^{18} \mathrm{O}_{\text {diatom }}$ data. The Baunt isotope record covers ca. 13.0 to $6.2 \mathrm{ka}$ cal $\mathrm{BP}$, and shows several distinct shifts. $\delta^{18} \mathrm{O}_{\text {diatom }}$ values range from $+22.7 \%$ o to $+32.1 \%$ o (Fig. 4), with a general

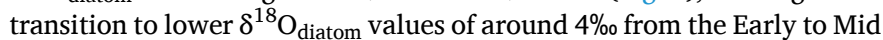
Holocene. The earliest section of the record from ca. 13.0 to $10.5 \mathrm{ka}$ cal BP documents low amplitude $\delta^{18} \mathrm{O}_{\text {diatom }}$ change between +25.9 and + $27.6 \%$ (Fig. 4), with the largest reduction at $\sim 10.5 \mathrm{ka}$ cal BP being greater than analytical error $(0.2 \%)$. Following this, the record shows large peaks and troughs, with values reaching over $+31.0 \%$ between $\sim 10.0 \mathrm{ka}$ cal BP and $\sim 8.4 \mathrm{ka} \mathrm{cal} \mathrm{BP}$, interrupted by transitions to lower $\delta^{18} \mathrm{O}_{\text {diatom }}$ values of $+25.3 \%$ at $\sim 9.8 \mathrm{ka} \mathrm{cal} \mathrm{BP}$ and $+25.5 \%$ at $\sim 8.8 \mathrm{ka}$ cal BP (although the lowest value of this decline is only recorded in one sample). After the final high value at $\sim 8.4 \mathrm{ka}$ cal $\mathrm{BP}$, the $\delta^{18} \mathrm{O}_{\text {diatom }}$ abruptly drops to $+26.8 \%$ by $\sim 8.1 \mathrm{ka}$ cal BP and then continues to decline to $+24.5 \%$ at $\sim 7.5 \mathrm{ka}$ cal BP. After this, values increase to 
$+27.2 \%$ by $\sim 6.9 \mathrm{ka}$ cal BP and then gradually decline from $+27.0 \%$ to $+24.5 \%$ by the end of the record at $\sim 6.2 \mathrm{ka}$ cal BP.

\subsection{Summary diatom record}

The most dominant diatom species, Aulacoseira granulata (Ehrenberg) Simonsen, Pantocsekiella ocellata (Pantocsek) K.T.Kiss and E.Ács and Tabellaria flocculosa (Roth) Kützing, found in BNT14 (Fig. 4) show limited change across the studied section, although $T$. flocculosa does increase in compositional importance from the Younger Dryas $(\sim 10 \%)$ to the Mid Holocene (up to $\sim 40 \%$ )(supplementary information). Sampling resolution matches the $\delta^{18} \mathrm{O}_{\text {diatom }}$ samples and ranges from samples every $\sim 600$ (Younger Dryas time period) to $\sim 20$ years (MidHolocene). All species are considered to be planktonic and represent the same environment. Total diatom flux is lower at the base of the start of the record and rises at $\sim 10.5 \mathrm{ka}$ cal BP, where after it fluctuates, while $F_{-}$index values are always above 0.9 , which indicate that dissolution within the samples is very limited.

\section{Discussion}

\subsection{Integrity of and controls on the new Lake Baunt $\delta^{18} O_{\text {diatom }}$} palaeolimnological record

Several factors can potentially complicate interpretation of $\delta^{18} \mathrm{O}_{\text {dia- }}$ tom data from palaeolimnological records, including contamination from other sedimentary oxygen-bearing minerals (e.g. clays, silts and tephras) (Brewer et al., 2008; Wilson et al., 2014), vital effects (van Hardenbroek et al., 2018), and taphonomic processes such as diatom dissolution (Smith et al., 2016). To account for potential contamination, we mass-

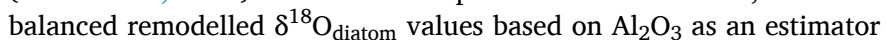
of contamination (Brewer et al., 2008), after having undertaken standard diatom purification procedures (Mackay et al., 2011; Morley et al., 2004; Wilson et al., 2014) (Fig. 5). Previous work suggests that vital and species effects on lacustrine diatoms are within analytical error (Swann et al., 2010; Swann et al., 2007; van Hardenbroek et al., 2018), however for Baunt vital effects are unlikely to be an issue because the same three planktonic species persist throughout the record, with relatively little variation (Fig. 4). Diatom dissolution can alter $\delta^{18} \mathrm{O}_{\text {diatom, }}$ causing a small negative effect (ca. $0.6 \%$ ) beyond analytical error (Smith et al., 2016), but the influence of diatom dissolution in Baunt is also considered to be minimal, due to the excellent preservation of diatoms across the whole core, with persistent $F_{-}$index vaues of above 0.9 (where higher values on the $0-1$ scale indicate lower dissolution) (Fig. 4; supplementary information).

As an open lake, and with no evidence of species effects or dissolution on the remodelled $\delta^{18} \mathrm{O}_{\text {diatom }}$ record, it is expected that Baunt's $\delta^{18} \mathrm{O}_{\text {diatom }}$ record will reflect changes in temperature and palae-

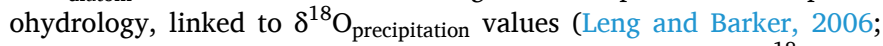
Leng and Marshall, 2004; Leng and Swann, 2010). The Baunt $\delta^{18} \mathrm{O}_{\text {diatom }}$ record has a range in values of $9.4 \%$, and if these were driven purely by changes in the lake water temperature, it indicates temperature changes through this period that appear unrealistic. This is because the Dansgaard temperature dependence relationship suggests that for every $1^{\circ} \mathrm{C}$

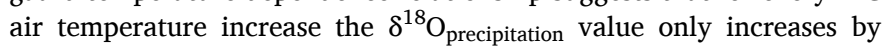
$+0.50 \%$ in Irkutsk (Kostrova et al., 2020). Alongside the air temperature fractionation, the diatom silica to water fractionation gradient is $-0.2 \% /{ }^{\circ} \mathrm{C}$ (Dodd and Sharp, 2010; Leng and Barker, 2006), and com-

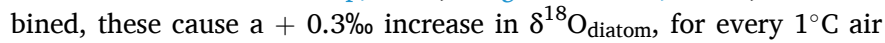
temperature increase. This would, therefore, suggest that to drive the change of $9.4 \%$ seen across the Baunt record, a change of $\sim 31.3^{\circ} \mathrm{C}$ in air temperature is needed. As a result of this, it is anticipated that the influence of temperature on the $\delta^{18} \mathrm{O}_{\text {diatom }}$ record is limited and other drivers are involved, with changes in $\delta^{18} \mathrm{O}_{\text {lakewater }}$ potentially related to variations in $\delta^{18} \mathrm{O}_{\text {precipitation and/or the hydrological conditions as }}$ determined by several previous studies (e.g. Cartier et al., 2019; Kostrova et al., 2019; Kostrova et al., 2013b; Meyer et al., 2015).The $\delta^{18} \mathrm{O}_{\text {lakewater }}$ samples from Baunt provide important information on the modern lake. The average Baunt $\delta^{18} \mathrm{O}_{\text {lakewater }}$ is $-16.0 \%$, with limited range, both across the lake and between surface and bottom water (Fig. 3), highlighting it is well mixed. The $\delta^{18} \mathrm{O}_{\text {lakewater }}$ is similar to the

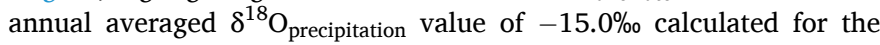
BNT14 core location (Bowen, 2020; Bowen et al., 2005). This is important as it is essential for the $\delta^{18} \mathrm{O}_{\text {lakewater }}$ to have averaged out local/seasonal $\delta^{18} \mathrm{O}$ variations in precipitation (Leng and Marshall, 2004), although the small differences between March and August values
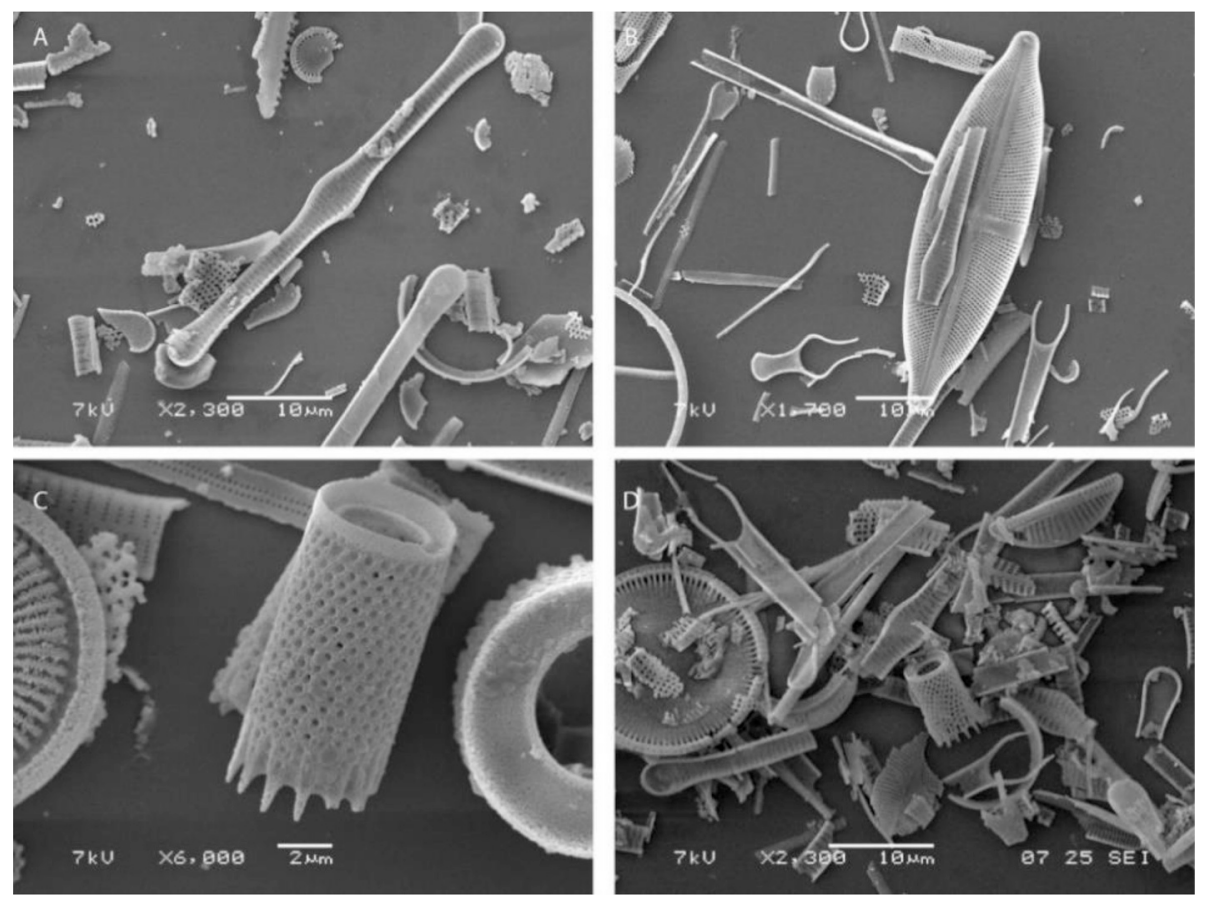

Fig. 5. Scanning Electron Microscopy Images of cleaned isotope samples from varying Lake Baunt Depths: (A) $0.05 \mathrm{~m}$, (B) $1.90 \mathrm{~m}$, (C) $3.75 \mathrm{~m}$, (D) $4.20 \mathrm{~m}$. 
highlight a minor seasonal influence. The $\delta^{18} \mathrm{O}_{\text {lakewater }}$ and $\delta \mathrm{D}_{\text {lakewater }}$ values are linearly correlated, with a slope of 7.4, and lie on the local meteoric water line (Fig. 3), indicating that, at present, evaporation does not have a significant affect, although we cannot discount evaporation having greater influence in the past.

Given the location of Lake Baunt and its catchment, the influence of several different atmospheric circulation systems controlling varying proportions of moisture from the different source regions, likely drives

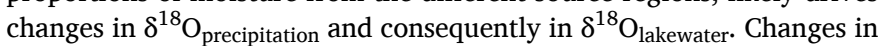
the strength of the Siberian High will also be important, with periods of increased strength reducing the overall summer precipitation levels and increasing the proportion of snowmelt entering the lake waters (Park et al., 2014; Tubi and Dayan, 2013), while during periods of weaker Siberian High, summer precipitation is proportionally more important. The varying proportion of snowmelt is also important, as the $\delta^{18} \mathrm{O}_{\text {snow }}$ has much lower values (suggested $\delta^{18} \mathrm{O}_{\text {snow }}$ of $-29.1 \%$ and $-41.4 \%$; data from Chizhova et al. (2015) and Kostrova et al. (2020) respectively), than the current summer (JJA) $\delta^{18} \mathrm{O}_{\text {precipitation values, which }}$ range between $\sim-12.8 \%$ (Chizhova et al., 2015) and $\sim-4.0 \%$ (Kostrova et al., 2020), and thus, changed proportions of these will in-

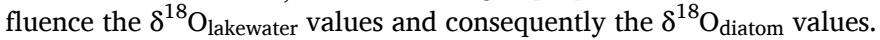

Similar controls are also important for driving changes in the Lake Baikal $\delta^{18} \mathrm{O}_{\text {diatom }}$ record as in Lake Baunt, with the different proportions of precipitation coming from different source regions being a driver of changes in the $\delta^{18} \mathrm{O}_{\text {lakewater, }}$ while Siberian High strength changes will also influence the proportional importance of summer or winter precipitation. In Baikal, changes in Siberian High strength are seen to trigger variations in the proportion of lake water coming from southern or northern rivers in its catchment, with increased proportions of snowmelt fed northern rivers when the Siberian High is strong and summer precipitation is limited. Glacier melting is also an important influence, particularly for the Vydrino cores, as these are taken off-shore from glaciers which flowed into Lake Baikal during the Younger Dryas and Early Holocene (Mackay et al., 2011). Like snowmelt, glacial meltwaters have lower $\delta^{18} \mathrm{O}$ values than summertime $\delta^{18} \mathrm{O}_{\text {precipitation, }}$ and thus, increased meltwaters can have substantial influences on the $\delta^{18} \mathrm{O}_{\text {lakewater }}$.

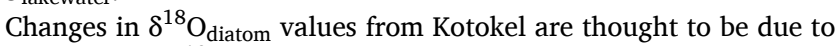
variations in the $\delta^{18} \mathrm{O}_{\text {lakewater }}$ in response to changes in air temperature, hydrology and atmospheric circulation (Kostrova et al., 2016).
Variations in the proportion of summer precipitation from different source regions are implicated in changes to the $\delta^{18} \mathrm{O}_{\text {diatom }}$ throughout the Holocene, with an increased share of precipitation from southern sources during the Early Holocene, with a shift to more Atlantic sourced moisture during the Mid-Late Holocene (Kostrova et al., 2016). Additionally, as a large but shallow lake, evaporation may also be a feature, although during the studied time period, this will be less influential than during its older history, when the lake was a closed basin, and thus, more strongly influenced by evaporation (Leng and Barker, 2006).

\subsection{Palaeohydrology of Lake Baunt and Southern Siberia}

\subsubsection{Palaeohydrology during the Younger Dryas in Lake Baunt and Southern Siberia $(\sim 12.4-11.7 \mathrm{ka}$ cal BP)}

Contrary to expectations, the Younger Dryas stadial does not show

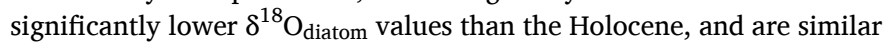
to the mean for the whole record (Figs. 4, 6, 7 and 8). Several factors may explain this, including the seasonality of the diatom record, as the isotopic signal is recorded during the growing season (Leng and Swann, 2010), with bulk samples tending to be averaged across the spring to the autumn. This indicates that the diatoms will be recording the springautumn conditions. Under modern conditions, seasonal variations in

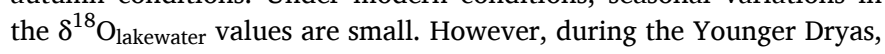
obliquity was increasing (Fig. 7), causing stronger seasonality in southern Siberia (Bush, 2005).This increased seasonality may have amplified the currently small seasonal variations in the $\delta^{18} \mathrm{O}_{\text {lakewater }}$ values, and could explain the limited differences $(\sim 1-2 \%$ ) between the $\delta^{18} \mathrm{O}_{\text {diatom }}$ values for the Younger Dryas and Early Holocene, with the $\delta^{18} \mathrm{O}_{\text {diatom }}$ values recording the average $\delta^{18} \mathrm{O}_{\text {lakewater }}$ for summertime conditions, when the Siberian High has dissipated and increased precipitation enters the region and, thus, $\delta^{18} \mathrm{O}_{\text {precipitation would be relatively }}$ consistent between the Younger Dryas and Early Holocene.

During the Younger Dryas, southern Siberia records from lakes Baunt, Baikal and Kotokel all range between $\sim+26$ to $+31 \%$ (Figs. 6, 7 and 8). Although the resolution of the isotope record in each lake during the Younger Dryas is low (samples every 100-600 years), with chronological uncertainties at Lake Baunt around \pm 150 years (Figs. 4,6,7 and 8). For Baikal and Baunt $\delta^{18} \mathrm{O}_{\text {diatom }}$ values are similar to the Mid Holocene and for Kotokel they are higher than the Holocene (Fig. 8). These support our interpretation that the Baunt $\delta^{18} \mathrm{O}_{\text {diatom }}$ record in the

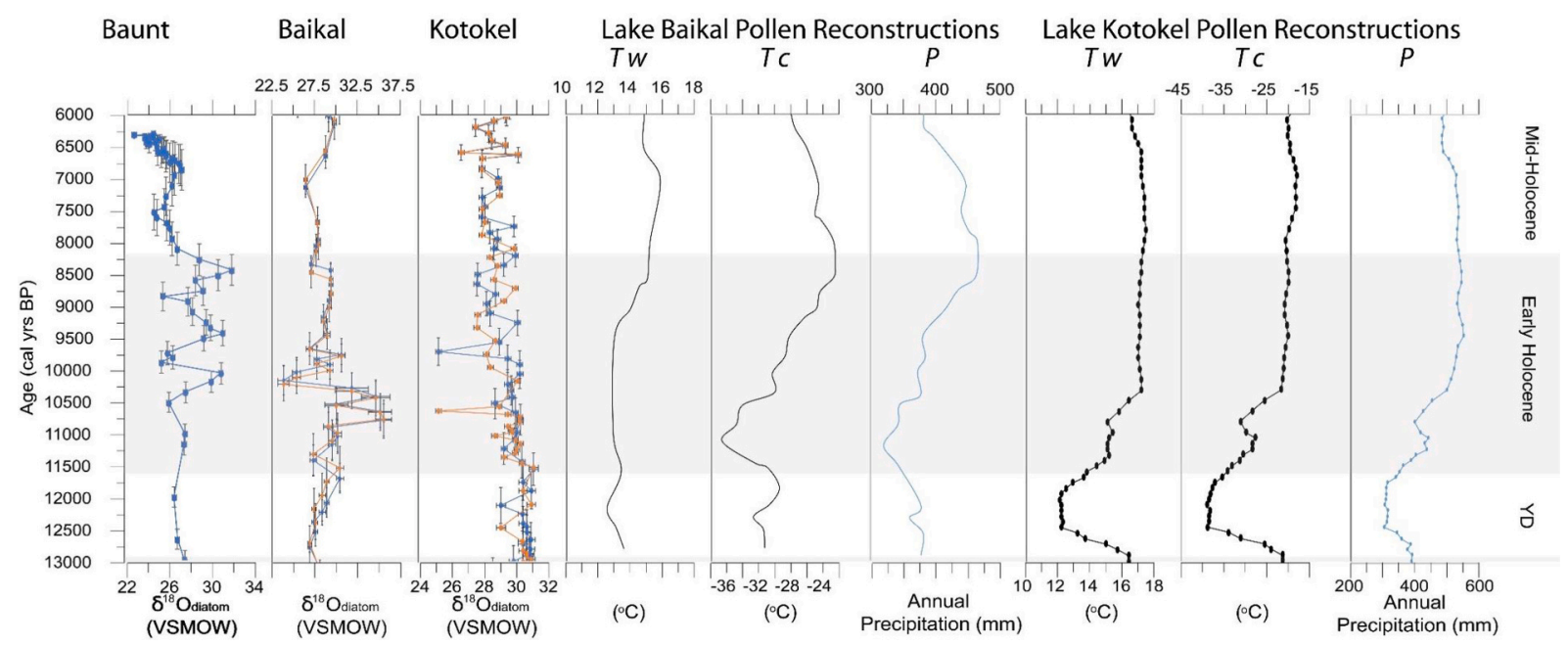

Fig. 6. Lake Baunt $\delta^{18} \mathrm{O}_{\text {diatom }}$ (VSMOW \%) (shown with chronological and analytical errors) alongside $\delta^{18} \mathrm{O}_{\text {diatom }}$ records (VSMOW \%o) from Lake Baikal (blue line, revised age model (this study), orange line, previous chronology (Mackay et al., 2011)) and Lake Kotokel (blue line, Siberian information age model (this study), orange line Bezrukova et al. (2010) chronology with transferred Lake Sihailongwan ages (Kostrova et al., 2013b, 2014, 2016) (both shown with analytical errors, chronological errors shown on revised model (blue)). Shown alongside Lake Baikal (Tarasov et al., 2007) and Lake Kotokel (Tarasov et al., 2009) pollen reconstructions: $T w\left({ }^{\circ} \mathrm{C}\right)$ (warmest month), $T c\left({ }^{\circ} \mathrm{C}\right)$ (coldest month) (3 point running averages) and $P$ pollen annual precipitation reconstruction (mm)(3 point running average) (Tarasov et al., 2007, 2009). (For interpretation of the references to colour in this figure legend, the reader is referred to the web version of this article). 


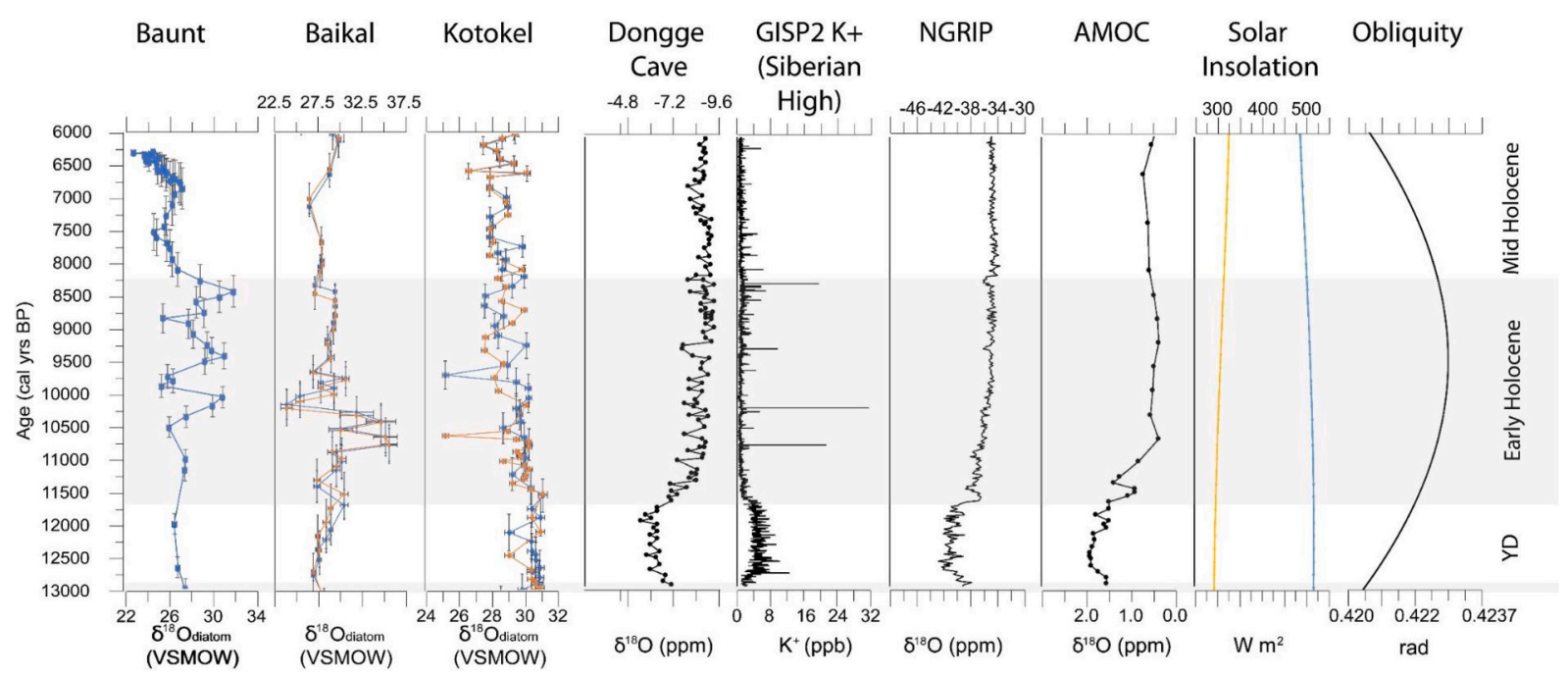

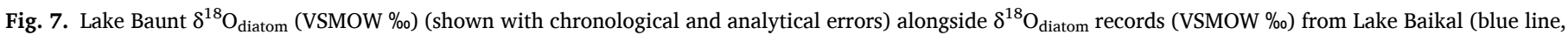

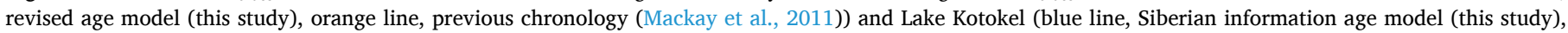

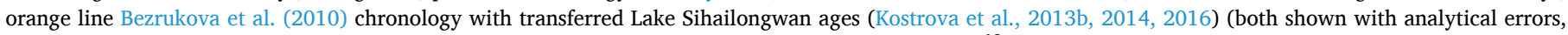

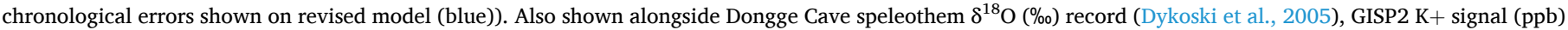

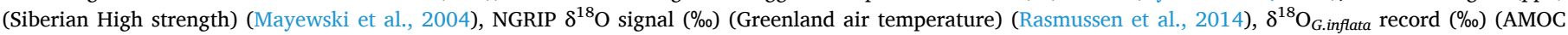

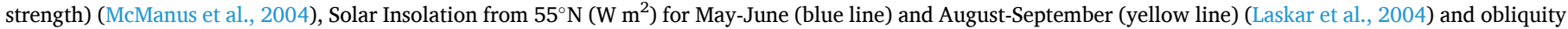

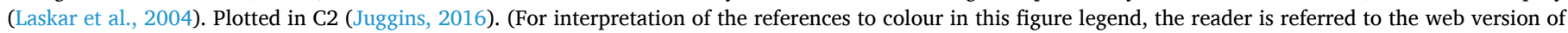
this article).

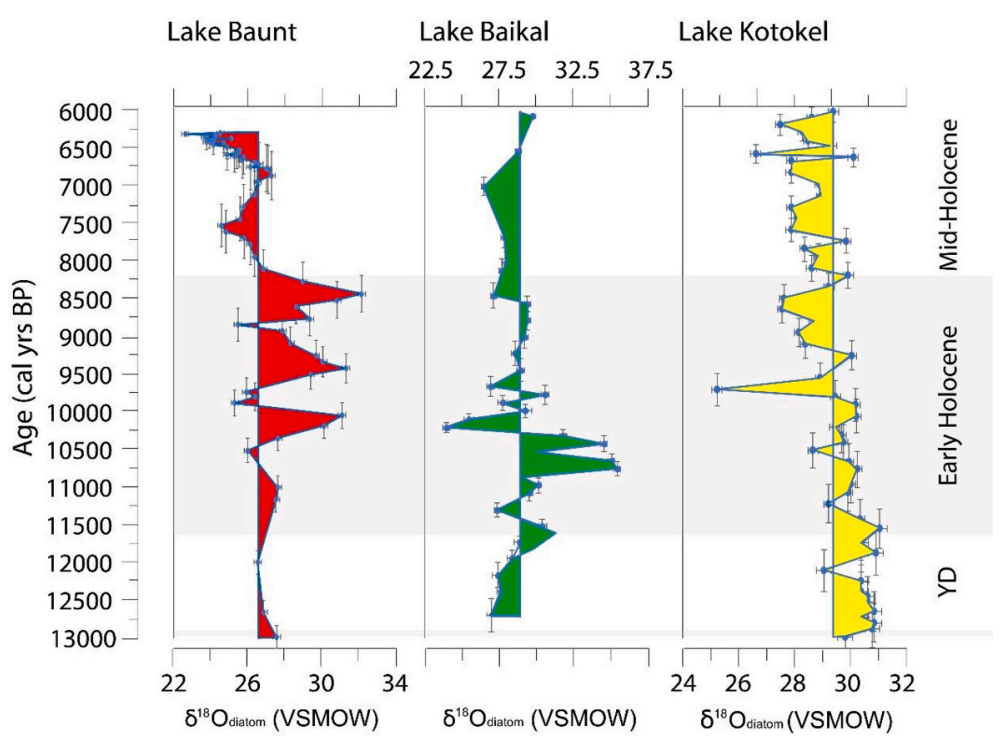

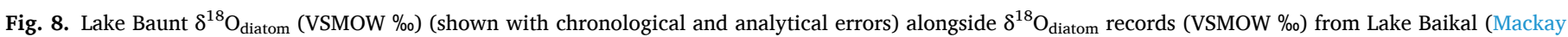

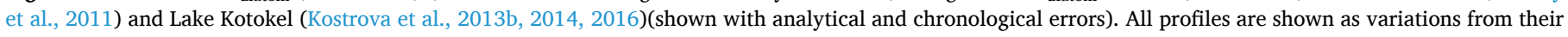
mean isotopic value.

Younger Dryas is influenced by the seasonality of the proxy.

Increased seasonality has been well documented in other proxy data from southern Siberia. Pollen evidence from both Baikal and Kotokel (Fig. 6) show significant seasonality (thermal minimum summer temperatures of $\sim 12^{\circ} \mathrm{C}$, versus winter temperatures $\sim-35^{\circ} \mathrm{C}$ ) (Tarasov et al., 2007, 2009). Moreover, for Baikal, summer temperatures for the Younger Dryas show no difference to the Early Holocene until the thermal maximum after $\sim 9 \mathrm{ka}$ cal BP and in Baikal only the first half of the Younger Dryas is cold in summer (Fig. 8). Pollen and $\delta^{18} \mathrm{O}_{\text {diatom }}$ records combined from Lake Baikal and Kotokel (Fig. 6) suggest increasing hydrological variability due to increased precipitation from $\sim 12.0 \mathrm{ka}$ cal BP, which has been taken to indicate the region was warming (Bezrukova et al., 2010; Mackay et al., 2011; Tarasov et al., 2007, 2009). In other regions of continental Eurasia, it has been proposed that while overall conditions were cold, summers in the Younger Dryas (GS-1) were relatively warm (Schenk et al., 2018). Taking these data as a whole, we assume, that increased seasonality during the Younger Dryas may be an important influence on the Baunt $\delta^{18} \mathrm{O}_{\text {diatom }}$ record.

4.2.2. The expression of the early Holocene in Lake Baunt and Southern Siberia (11.7-8.2 ka cal BP)

The Early Holocene in the Baunt record reveals considerable $\delta^{18} \mathrm{O}_{\text {diatom }}$ variability, with peak values occurring at $\sim 10.0(31.0 \%), 9.4$ 
(31.2\%) and $\sim 8.4(32.1 \%$ o ka cal BP, interrupted by lows at $\sim 10.5$ $(25.9 \%$ o),$\sim 9.8(25.3 \%$ o), $\sim 8.8(25.5 \%$ o $)$ and $\sim 8.1(26.8 \%$ o) ka cal BP. The amplitude of these changes, between $+24 \%$ o to $+32 \%$ o $(8 \%$ ), are indicative of major hydrological variability. The higher $\delta^{18} \mathrm{O}_{\text {diatom }}$ values during the Early Holocene could be highlighting a response to high insolation values, and, thus, warmer temperatures (Fig. 7), however, higher air temperatures alone, as discussed in Section 4.1, are not large enough to drive the values seen from $\sim 10.0 \mathrm{ka}$ cal BP at Baunt.

Previous regional studies have implicated different proportions of precipitation from some air masses to explain higher Early Holocene $\delta^{18} \mathrm{O}_{\text {diatom }}$ values (Kostrova et al., 2013b, 2014, 2016). As discussed in Section 1.1, the Baikal-Transbaikal region is influenced by several atmospheric circulation systems and therefore, an additional factor to consider is varying precipitation quantities and source regions. Available isotope data and models for the wider Siberian region and southern regions of Mongolia and China, from the Global Network isotopes in Precipitation (GNIP), specifically the Regionalized Cluster-Based Water Isotope Prediction (RCWIP) model (Terzer et al., 2013), allows this to be considered further (Fig. 9). Currently, central and western Siberian sites

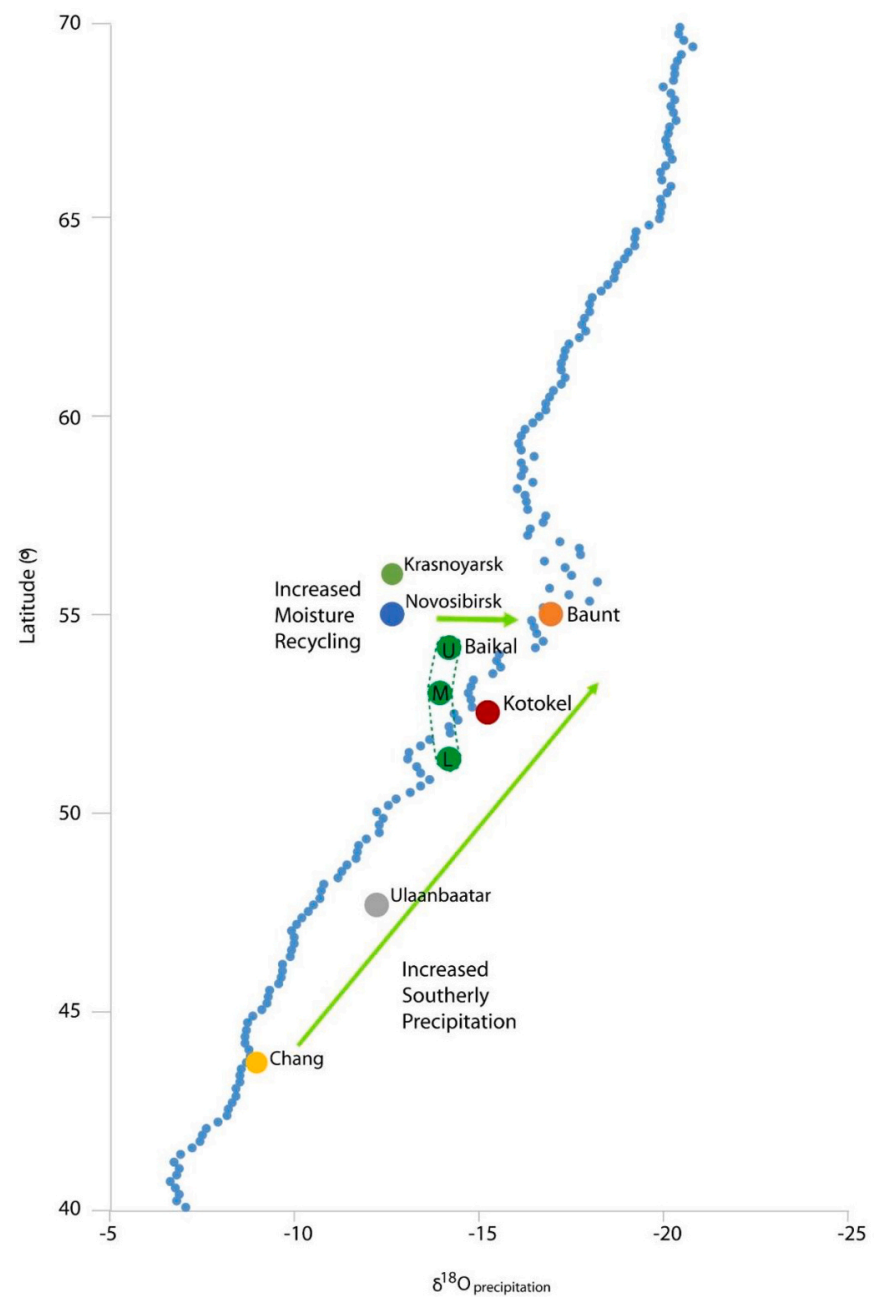

Fig. 9. Regionalized Cluster-Based Water Isotope Prediction (RCWIP) model annual average output for $\delta^{18} \mathrm{O}_{\text {preciptation }}$ in 2018 (Terzer et al., 2013) from the Global Network isotopes in Precipitation (GNIP) monitoring network. Showing Lake Baunt (orange), Lake Kotokel (red), Lake Baikal (three green markers for Upper, Middle and Lower basins, joined by dotted lines), plotted against data for western central Siberian sites (blue - Novosibirsk and green -Krasnoyarsk, Mongolian (grey - Ulaanbaatar) and a Chinese site (yellow - Chang Chun) plotted against a transect of $\delta^{18} \mathrm{O}_{\text {preciptation }}$ gridded data for $113^{\circ}$ longitude on a North-South latitudinal transect. (For interpretation of the references to colour in this figure legend, the reader is referred to the web version of this article).



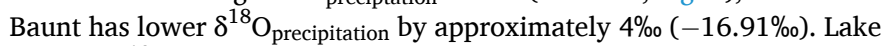
Baikal's $\delta^{18} \mathrm{O}_{\text {preciptation }}$ is also lower than these central and western sites at $\sim-14 \%$, while Kotokel sits at $-15.81 \%$ (Fig. 9). The lower $\delta^{18} \mathrm{O}_{\text {preciptation }}$ values at Kotokel, Baikal, and most notably Baunt, therefore, seem to be linked to the additional recycling of westerly derived moisture, and the more north eastern position of Baunt compared to Baikal and Kotokel seems to exacerbate this, while also reducing the proportion of southern sourced summertime precipitation reaching the site.

It is possible that weakening of the Siberian High, as a result of high solar insolation during the Early Holocene (Fig. 7), allowed for increased quantity and an extended period of summertime precipitation This resulted in increased influence of summer precipitation on the $\delta^{18} \mathrm{O}_{\text {la }}$ kewater values, and subsequently on the $\delta^{18} \mathrm{O}_{\text {diatom values. Additionally, a }}$ weaker Siberian High may have increased the proportion of southern sourced precipitation reaching the Baikal-Transbaikal region. For Lake Baunt, an increased proportion in southern sourced precipitation could induce a shift to higher $\delta^{18} \mathrm{O}_{\text {lakewater values and consequently } \delta^{18} \mathrm{O}_{\text {diatom }}}$ values, as $\delta^{18} \mathrm{O}_{\text {preciptation }}$ from southern sources are isotopically higher (Fig. 9). This is shown in the $\delta^{18} \mathrm{O}_{\text {preciptation values from more southern }}$ sites in Mongolia and China (Fig. 9), which have considerably higher $\left(\sim 8 \%\right.$ difference) isotopic values than $\delta^{18} \mathrm{O}_{\text {preciptation }}$ in the Lake Baunt region, reflecting the influence of southerly sources. As modern studies (Section 1.1) highlight that summertime precipitation in the BaikalTransbaikal region currently includes a proportion of precipitation from southern sources, it is possible that increased quantities of precipitation from these sources could account for the high $\delta^{18} \mathrm{O}_{\text {diatom }}$ values seen in the Early Holocene.

A further factor that must be considered to understand the $\delta^{18} \mathrm{O}_{\text {diatom }}$ signal in the Early Holocene at Lake Baunt is the variation in the solar insolation received in different seasons during the Early Holocene. This is important, as the insolation received in the early summer (May-June) is substantially higher than the insolation received in mid-late summer (August-September) (Fig. 7). The diatom species found in the Lake Baunt record (Fig. 4) are likely to be being influenced more greatly by the later summer insolation, particularly due to presence of $A$. granulata, which is often considered to bloom in the late summer during when waters have warmed and overturning occurs (Kilham and Kilham, 1975; O'Farrell et al., 2001). This species is heavily silicified and contributes substantially to the silica preserved in Baunt (Chen et al., 2012; Kilham et al., 1986), and therefore, it is likely the diatoms are again introducing a bias in the record, to mid-late summer conditions, and this could delay a record of Early Holocene warming linked to increased insolation being recorded.

The occurrence of higher $\delta^{18} \mathrm{O}_{\text {diatom }}$ values at Lake Baunt during the Early Holocene, could, therefore, be a hydrological response to orbitally forced climate changes, leading to changes in solar insolation that then influence changes in precipitation source proportions and quantity. However, this alone cannot explain the variability seen in the $\delta^{18} \mathrm{O}_{\text {diatom }}$ record during this period. The Early Holocene is known to have several abrupt climate shifts superimposed over the longer term changes, and here we consider if the variability in the Baunt $\delta^{18} \mathrm{O}_{\text {diatom }}$ record is documenting responses to locally driven changes, or extrinsically forced shifts, with comparison with nearby lakes Baikal and Kotokel. When considering Lake Baunt alongside Lake Baikal, it is notable that both records document large amplitude $\delta^{18} \mathrm{O}_{\text {diatom }}$ shifts during the Early Holocene (Figs. 6, 7 and 8), indicative of considerable hydrological variability (Mackay et al., 2011). Their occurrence between the two records are, however, offset, with greatest variability in Baikal occurring between $\sim 11-9.5 \mathrm{ka}$ cal BP, and later at $\sim 10.5-8.5 \mathrm{ka}$ cal BP at Baunt. This highlights that based on current chronological controls, peak variability occurs earlier at the more southern Lake Baikal location, possibly linked to increased regional glacier melt (Mackay et al., 2011). Mackay et al. (2011) interpret these abrupt declines in $\delta^{18} \mathrm{O}_{\text {diatom }}$ values in relation to ice-rafted debris evidence in North Atlantic sediments 
(Bond et al., 2001) indicative of slow-down of the Atlantic Meridional Overturning Circulation (AMOC) linked to fresh meltwater outbursts (Broecker, 1994).

In the case of Lake Baikal, the earlier onset of instability compared to Baunt could be produced by several factors. The most notable is the significant differences in catchment sizes between the two lakes, with the Lake Baikal catchment extending to much more southerly latitudes than Baunt. Moreover, the Vydrino location of Lake Baikal studied by Mackay et al. (2011) is offshore from glaciers flowing into the south basin at that time. The more northernly location of glaciers affecting Lake Baunt may not have melted as rapidly or as strongly as those in regions to the south, and glaciers in the Baunt area tend to be mountain glaciers, located away from lake (Margold et al., 2016), and therefore, there influence will differ from the glaciers closely located to Baikal. The higher $\delta^{18} \mathrm{O}_{\text {diatom }}$ reported for the Early Holocene in Lake Baikal have been explained as being sourced through the influence of the southerly catchment from the Selenga River, contrasting with lower values through greater influence of rivers to the north (Mackay et al., 2011), coincident with reduced AMOC and increased IRD fluxes in the North Atlantic. There is a $\sim 7 \%$ difference in the $\delta^{18} \mathrm{O}$ between these source waters (Mackay et al., 2011), and this seems to explain Baikal $\delta^{18} \mathrm{O}_{\text {diatom }}$ during the Early Holocene. The highest $\delta^{18} \mathrm{O}_{\text {diatom values in Baunt are }}$ $\sim 4 \%$ lower than the highest value in Baikal, although the lowest in both are similar. Additionally to this, the complete Baunt records mean values are significantly lower than the Baikal values (supplementary information), and this indicates that the more north eastern position of Baunt and its more localised catchment, are likely to explain the lower peak values recorded in Baunt, compared to Baikal. In addition, the long residence time of water in Lake Baikal (330 years (Mackay et al., 2011)) may also be a driver of some of the discrepancies between the two lakes, as due to its smaller size and open nature, this is anticipated to be much shorter for Baunt.

When Lake Baunt is considered against Lake Kotokel, it is notable that variability in the Kotokel record is much more limited than that seen at Baunt (supplementary information). However, during the Early Holocene, $\delta^{18} \mathrm{O}_{\text {diatom }}$ values at Kotokel reach levels of $29-30 \%$, which are only slightly $(\sim 1-2 \%$ ) lower than the peaks documented at Lake Baunt. These values at Kotokel are considered to correspond to periods of high summer insolation (Fig. 7), and, as discussed above, increased proportions of precipitation from southern sources (Kostrova et al., 2013a, 2013b, 2014, 2016). This suggests both lakes are responding to the same driver, but the larger increase in values seen at Baunt are linked to its more northern position, meaning that, prior to the Early Holocene, the levels of southern precipitation reaching the site are likely to have been lower than Kotokel, and thus, an increase in lighter isotopes could cause a rapid shift in values. Slight declines in values at Kotokel during the earliest period of the Holocene have been linked to permafrost degradation and increased meltwaters (Bezrukova et al., 2010; Kostrova et al., 2016). These variations occur before shifts occur in Baunt, and this supports the findings from Baikal, suggesting that more southern sites undergo stronger glacier melting and permafrost thawing, while northern regions were later to respond. Finally, the reduced variation in the Kotokel record, compared to Baunt and Baikal, may be a result of the different characteristics of the lake, with its short residence time (7 years) (Shichi et al., 2009)(particularly compared with the long $\sim 330$ year residence time of Lake Baikal (Mackay et al., 2011)), shallower depth (Bezrukova et al., 2010; Kostrova et al., 2013b, 2014, 2016) and close proximity to Baikal potentially all dampening the variability in $\delta^{18} \mathrm{O}_{\text {diatom }}$ record.

Pollen reconstructions from Kotokel and Baikal allow greater consideration of the regional landscape during this period. Both records show increasing winter temperatures, and Kotokel shows summer temperature rises, alongside annual precipitation values rising from the start of the Holocene, they do not reach peak levels until $\sim 10.3 \mathrm{ka}$ cal BP at Kotokel, and $\sim 9.0 \mathrm{ka}$ cal BP in Baikal (Tarasov et al., 2007, 2009) (Fig. 6). This suggests that the earlier shifts in the Lake Baikal $\delta^{18} \mathrm{O}_{\text {diatom }}$ record are likely to be due to the influence of the Selenga and it's southern catchment, while the Baunt signal is more likely to be representative of local conditions in its much more limited catchment. Therefore, it is also worth noting that the lag in the shift to higher $\delta^{18} \mathrm{O}_{\text {diatom }}$ values in Baunt, by comparison to Baikal (Figs. 6 and 7), may reflect not only the southerly catchment influence on Baikal, but also the more northerly position of Baunt.

From $\sim 10.5 \mathrm{ka}$ cal BP, Baunt begins to have evidence for large amplitude fluctuations. A decline in $\delta^{18} \mathrm{O}_{\text {diatom values in BNT14 at }}$ $\sim 10.5 \pm 0.16$ may therefore appear small, but is important, as it may highlight an important shift in the regions climate, potentially showing a response to the start of regional glacial melt, as documented during the very early Holocene further south at Lake Kotokel (Bezrukova et al., 2010; Kostrova et al., 2016).

The large shift in the Baunt $\delta^{18} \mathrm{O}_{\text {diatom }}$ record at $\sim 9.8 \pm 0.18 \mathrm{ka} \mathrm{cal}$ $\mathrm{BP}$ is the most sustained during Early Holocene and occurs after the site has shown evidence of responses to increased annual temperature and precipitation during the Early Holocene, as suggested by higher $\delta^{18} \mathrm{O}_{\text {diatom }}$ values. A decline to lower values in Baikal at $10.1 \pm 0.23$ overlaps with this event in Baunt, suggesting the two sites may be responding to the same forcings. At Baikal this has been suggested to occur synchronously with wider northern hemisphere cooling (linked to a strong Siberian High, as indicated by peak GISP2 K+ values in Fig. 7), documented in both the North Atlantic and Greenland (Bond, 1997; McManus et al., 2004; Rasmussen et al., 2014), however the timeframe of the Baunt shift does not overlap with the $\sim 10.3$ event considered to be documented in the Baikal record. It may then be, that the records are both responding to more local forcings, or that the event in Baikal is not triggering a response to be recorded in Baunt. For Lake Baunt at this time, we consider that as previous values at $\sim 10.0 \mathrm{ka}$ cal BP reached $+31.0 \%$, it is likely Early Holocene warming, linked to orbital changes, triggered an increase in glacier melt local to Baunt. As $\delta^{18} \mathrm{O}_{\text {snowmelt }}$ is much lower than precipitation (Kostrova et al., 2020), this may be driving the decline to lower $\delta^{18} \mathrm{O}_{\text {diatom }}$ values. A further small decline at $\sim 9.6+0.11$ in Baikal is not correlated to any Siberian High shifts (Fig. 7) and therefore, may indicate as response to in-wash from melting glaciers, again highlighting the influence of local factors for driving changes in the $\delta^{18} \mathrm{O}_{\text {diatom }}$ records (Mackay et al., 2011).

A further decline in Baunt's $\delta^{18} \mathrm{O}_{\text {diatom }}$ values occurs at $\sim 8.1 \pm 0.26$ ka cal BP, following the last of the final Early Holocene higher $\delta^{18} \mathrm{O}_{\text {diatom }}$ values at $8.4 \pm 0.25$, and values continue to decline following this into the Mid Holocene. This decline is interesting, as while it coincides with the widely documented 8.2 BP event, and a significant shift in Siberian High strength (Fig. 7), isotopic values do not return to previous levels once the event has ended. The $\delta^{18} \mathrm{O}_{\text {diatom }}$ record from Kotokel does not record an event at this time, while a small shift in Baikal at $\sim 8.3 \pm 0.1$ is minor in comparison to previous fluctuations. This period, however, is critical within all three records, as it marks the transition from Early Holocene into Mid Holocene hydrological conditions. All three records document a persistent shift to values below the records mean (Fig. 8), while pollen reconstructions from Baikal and Kotokel show reduced precipitation from around $\sim 8 \mathrm{ka}$ cal BP (Fig. 6).

\subsubsection{The expression of the mid Holocene in Lake Baunt and Southern} Siberia $(\sim 8.2-6.2 \mathrm{ka}$ cal $\mathrm{BP})$

The reduction in the amplitude of changes after $\sim 8.2 \mathrm{ka}$ cal BP in the Baunt $\delta^{18} \mathrm{O}_{\text {diatom }}$ record may be linked to several factors, including the increased stability in the Siberian High (Fig. 7) and as a result of local glaciation being limited to small mountain glaciers by this point (Margold et al., 2016), reducing the potential input of meltwaters directly into the lake. It is also possible that the Mid Holocene marks the onset of modern configuration of moisture sources to Baunt, and this appears to be supported by the greater stability in the Baikal $\delta^{18} \mathrm{O}_{\text {diatom values. The }}$ shift to conditions more alike those in the modern day are also supported by the pollen precipitation reconstructions, which indicate values in a range closer to the current time in Baikal and Kotokel (Tarasov et al., 
2007, 2009) (Fig. 6). This shift to conditions more similar to those found currently in the region may, therefore, be a driver of the greater stability documented in $\delta^{18} \mathrm{O}_{\text {diatom }}$ values. Alongside the stability seen in Baunt and Baikal compared to the Early Holocene, all records show a general shift to values lower than their means across this period (Fig. 8). This

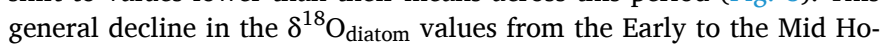
locene supports the suggestion put forward by Kostrova et al. (2013a, 2014, 2016), that during the Early Holocene a greater proportion of moisture was sourced from southern sources, causing generally higher $\delta^{18} \mathrm{O}_{\text {diatom }}$ values, while during the Mid Holocene, an increased amount of summertime precipitation was sourced from the Atlantic, reaching the region as recycled rainfall (Kostrova et al., 2013a, 2014, 2016). The combined evidence from these lakes, therefore, demonstrate an important shift in the proportion of moisture from different sources between the Early to Mid Holocene. This is important, as future change within this sensitive region may bring out further changes in the proportion of moisture from different sources, altering the region's water balance.

In addition to the influence of changing proportions of moisture sources, the Mid Holocene also occurs as total solar insolation decreases and the relative proportion of precession increases, while obliquity declines, causing reduced seasonality (Fig. 7). It is, therefore, likely that across the Mid Holocene, the record is documenting a response to changes in atmospheric circulation beyond the Siberian region, driving changes in the proportions of moisture from different source regions, alongside orbitally forced climate changes.

\section{Conclusions}

The Lake Baunt $\delta^{18} \mathrm{O}_{\text {diatom }}$ record highlights several shifts between $\sim 13.0-6.2 \mathrm{ka}$ cal BP. These group into three sections, a stable early period between $\sim 13.0-11.7 \mathrm{ka}$ cal BP, a phase with large magnitude abrupt oscillations during the Early Holocene (11.7-8.2 ka cal BP) and a more muted period during the Mid Holocene ( $\sim 8.2-6.2 \mathrm{ka}$ cal BP), but still with some variability. These appear to reflect changes in several factors, including the source, quantity and seasonality of precipitation, as well as air temperature and also long term solar insolation trends. The Younger Dryas signal at Lake Baunt is muted, potentially due to a summer season bias introduced by the diatoms, when strong seasonality driven by obliquity allows short but warm summers. During the Early Holocene higher $\delta^{18} \mathrm{O}_{\text {diatom }}$ values reflect the influence of high solar insolation, although this signal is delayed at Baunt, compared to more southerly records. High solar insolation induces changes in temperature and atmospheric dynamics that lead to these elevated $\delta^{18} \mathrm{O}_{\text {diatom }}$ values. These are punctuated by abrupt declines in $\delta^{18} \mathrm{O}_{\text {diatom }}$ values, which appear to be linked to local changes, particularly glacier melt. These, alongside site specific factors, notably catchment and lake size and location, explain much of the variations between the individual records from lakes in this region. This highlights the extreme sensitivity of this region, to internal variability and extrinsic forcing during times of climatic instability.

\section{Declaration of Competing Interest}

The authors declare that they have no known competing financial interests or personal relationships that could have appeared to influence the work reported in this paper.

\section{Acknowledgements}

This work was supported by a London-NERC-DTP studentship (NERC training grant code: NE/L002485/1) and isotope analyses were funded by the National Environmental Isotope Facility (IP-1725-0517) with technical support from Hilary Sloane and Jack Lacey. Additionally, this study was performed as part of the State Research Program of IGC SB RAS IX.127.1.2 from Ministry of Education and Science of the Russian Federation, Integration Project SB RAS (grant 0341-2017-0001), RSF (grant 19-17-00216, field works), RFBR (grant 20-05-00247) and Program of Government of the Russian Federation (project 075-15-2019866). Two radiocarbon dates were provided by the Quaternary Research Association Chrono Award and analysed at Queens University Belfast. We thank Prof. Paula Reimer for her help with sample selection and preparation. We also thank Dr. Handong Yang (UCL) for analysis of the ${ }^{210} \mathrm{~Pb}$ profile and Jim Davy for his help with SEM work. Finally, we thank the reviewers for their thorough and constructive comments on the manuscript.

\section{Appendix A. Supplementary data}

Supplementary data to this article can be found online at https://doi. org/10.1016/j.gloplacha.2020.103333.

\section{References}

Alpat'ev, A.M., Arkhangel'skii, A.M., Podoplelov, N.Y., Stepanov, A.Y., 1976. Physical Geography of the USSR (Asiatic Part). Vysshaya Shkola, Moscow.

Anchukaitis, K.J., Buckley, B.M., Cook, E.R., Cook, B.I., D'Arrigo, R.D., Ammann, C.M., 2010. Influence of volcanic eruptions on the climate of the Asian monsoon region. Geophys. Res. Lett. 37, L22703 https://doi.org/10.1029/2010GL044843.

Anekhonov, O.A., 1995. Vegetation of the Baunt Basin (Northern Transbaikalia). Novosibirsk.

Appleby, P.G., 2002. Chronostratigraphic Techniques in Recent Sediments, in: Tracking Environmental Change Using Lake Sediments. Kluwer Academic Publishers, Dordrecht, pp. 171-203. https://doi.org/10.1007/0-306-47669-X_9.

Appleby, P.G., Nolan, P.J., Gifford, D.W., Godfrey, M.J., Oldfield, F., Anderson, N.J., Battarbee, R.W., 1986. 210Pb dating by low background gamma counting. Hydrobiologia 143, 21-27. https://doi.org/10.1007/BF00026640.

Bakke, J., Lie, Ø., Heegaard, E., Dokken, T., Haug, G.H., Birks, H.H., Dulski, P., Nilsen, T., 2009. Rapid oceanic and atmospheric changes during the Younger Dryas cold period. Nat. Geosci. 2, 202-205. https://doi.org/10.1038/ngeo439.

Barber, D.C., Dyke, A., Hillaire-Marcel, C., Jennings, A.E., Andrews, J.T., Kerwin, M.W., Bilodeau, G., McNeely, R., Southon, J., Morehead, M.D., Gagnon, J.-M., 1999. Forcing of the cold event of 8,200 years ago by catastrophic drainage of Laurentide lakes. Nature 400, 344-348. https://doi.org/10.1038/22504.

Battarbee, R., Juggins, S., Gasse, F., Anderson, N., Bennion, H., Cameron, N., Ryves, D., Pailles, C., Chalie, F., Telford, R., 2001. An Information System for Palaeoenvironmental Reconstruction, 81. EDDI, pp. 1-94.

Bezrukova, E.V., Tarasov, P.E., Solovieva, N., Krivonogov, S.K., Riedel, F., 2010. Last glacial-interglacial vegetation and environmental dynamics in Southern Siberia: chronology, forcing and feedbacks. Palaeogeogr. Palaeoclimatol. Palaeoecol. 296, 185-198. https://doi.org/10.1016/j.palaeo.2010.07.020.

Bezrukova, E.V., Amosova, A.A., Chubarov, V.M., Finkelshtein, A.L., Kulagina, N.V., 2017. Environmental changes in the Northeast of the Buryat republic during the holocene post-optimum: first results. Contemp. Probl. Ecol. 10, 431-440. https:// doi.org/10.1134/S1995425517040011.

Biskaborn, B.K., Subetto, D.A., Savelieva, L.A., Vakhrameeva, P.S., Hansche, A., Herzschuh, U., Klemm, J., Heinecke, L., Pestryakova, L.A., Meyer, H., Kuhn, G., Diekmann, B., 2016. Late Quaternary vegetation and lake system dynamics in NorthEastern Siberia: implications for seasonal climate variability. Quat. Sci. Rev. 147, 406-421. https://doi.org/10.1016/J.QUASCIREV.2015.08.014.

Blockley, S.P.E., Lane, C.S., Hardiman, M., Rasmussen, S.O., Seierstad, I.K., Steffensen, J. P., Svensson, A., Lotter, A.F., Turney, C.S.M.M., Bronk Ramsey, C., 2012.

Synchronisation of palaeoenvironmental records over the last 60,000 years, and an extended INTIMATE 1 event stratigraphy to 48,000 b2k. Quat. Sci. Rev. 36, 2-10. https://doi.org/10.1016/j.quascirev.2011.09.017.

Blockley, S.P.E., Candy, I., Matthews, I., Langdon, P., Langdon, C., Palmer, A., Lincoln, P., Abrook, A., Taylor, B., Conneller, C., Bayliss, A., MacLeod, A., Deeprose, L., Darvill, C., Kearney, R., Beavan, N., Staff, R, Bamforth, M., Taylor, M., Milner, N., 2018. The resilience of postglacial hunter-gatherers to abrupt climate change. Nat. Ecol. Evol. 2, 810-818. https://doi.org/10.1038/s41559-018-0508-4.

Bond, G., 1997. A pervasive millennial-scale cycle in North Atlantic holocene and glacial climates. Science 278, 1257-1266. https://doi.org/10.1126/science.278.5341.1257.

Bond, G., Kromer, B., Beer, J., Muscheler, R., Evans, M.N., Showers, W., Hoffmann, S., Lotti-Bond, R., Hajdas, I., Bonani, G., 2001. Persistent solar influence on North Atlantic climate during the Holocene. Science 294, 2130-2136. https://doi.org/ 10.1126/science.1065680.

Bowen, G.J., 2020. The Online Isotopes in Precipitation Calculator [WWW Document]. version OIPC3.1 (4/2017). URL. http://www.waterisotopes.org.

Bowen, G.J., Wassenaar, L.I., Hobson, K.A., 2005. Global application of stable hydrogen and oxygen isotopes to wildlife forensics. Oecologia 143, 337-348. https://doi.org/ 10.1007/s00442-004-1813-y.

Brauer, A., Haug, G.H., Dulski, P., Sigman, D.M., Negendank, J.F.W., 2008. An abrupt wind shift in western Europe at the onset of the Younger Dryas cold period. Nat. Geosci. 1, 520-523. https://doi.org/10.1038/ngeo263.

Brewer, T.S., Leng, M.J., Mackay, A.W., Lamb, A.L., Tyler, J.J., Marsh, N.G., 2008. Unravelling contamination signals in biogenic silica oxygen isotope composition: the role of major and trace element geochemistry. J. Quat. Sci. 23, 321-330. https://doi. org/10.1002/jqs.1171. 
Broecker, W.S., 1994. Massive iceberg discharges as triggers for global climate change. Nature 372, 421-424. https://doi.org/10.1038/372421a0.

Bronk Ramsey, C., 2008. Deposition models for chronological records. Quat. Sci. Rev. 27, 42-60. https://doi.org/10.1016/j.quascirev.2007.01.019.

Bronk Ramsey, C., 2009a. Dealing with outliers and offsets in radiocarbon dating. Radiocarbon 51, 1023-1045. https://doi.org/10.1017/S0033822200034093.

Bronk Ramsey, C., 2009b. Bayesian analysis of radiocarbon dates. Radiocarbon 51, 337-360. https://doi.org/10.2458/azu js_rc.v51i1.3494.

Bronk Ramsey, C., Lee, S., 2013. Recent and planned developments of the program OxCal. Radiocarbon 55, 720-730. https://doi.org/10.2458/azu_js_rc.55.16215.

Brooks, S.J., Matthews, I.P., Birks, H.H., Birks, H.J.B., 2012. High resolution Lateglacial and early-Holocene summer air temperature records from Scotland inferred from chironomid assemblages. Quat. Sci. Rev. 41, 67-82. https://doi.org/10.1016/j. quascirev.2012.03.007.

Bush, A.B.G., 2005. CO 2 /H $2 \mathrm{O}$ and orbitally driven climate variability over Central Asia through the Holocene. Quat. Int. 136, 15-23. https://doi.org/10.1016/j. quaint.2004.11.004.

Cartier, R., Sylvestre, F., Paillès, C., Sonzogni, C., Couapel, M., Alexandre, A., Mazur, J. C., Brisset, E., Miramont, C., Guiter, F., 2019. Diatom-oxygen isotope record from high-altitude Lake Petit (2200 m a.s.l.) in the Mediterranean Alps: shedding light on a climatic pulse at 4.2 ka. Clim. Past 15, 253-263. https://doi.org/10.5194/cp-15253-2019.

Chen, X., Yang, X., Dong, X., Liu, E., 2012. Influence of environmental and spatial factors on the distribution of surface sediment diatoms in Chaohu Lake, Southeast China. Acta Bot. Croat 71, 299-310. https://doi.org/10.2478/v10184-011-0070-5.

Chizhova, J.N., Vasilchuk, J.Y., Yoshikawa, K., Budantseva, N.A., Golovanov, D.L., Sorokina, O.I., Stanilovskaya, J.V., Vasil'chuk, Y.K., 2015. Isotope composition of snow cover in the Lake Baikal area. Ice Snow 55, 55-66. https://doi.org/10.15356/ 2076-6734-2015-3-55-66.

Cole-Dai, J., Ferris, D.G., Lanciki, A.L., Savarino, J., Thiemens, M.H., McConnell, J.R., 2013. Two likely stratospheric volcanic eruptions in the 1450s C.E. found in a bipolar, subannually dated 800 year ice core record. J. Geophys. Res. Atmos. 118, 7459-7466. https://doi.org/10.1002/jgrd.50587.

Collins, M., Knutti, R., Arblaster, J., Dufresne, J.-L., Fichefet, T., Friedlingstein, P., Gao, X., Gutowski, W.J., Johns, T., Krinner, G., Shongwe, M., Tebaldi, C., Weaver, A. J., Wehner, M., 2013. Long-term Climate change: projections, commitments and irreversibility. In: Stocker, T.F., Qin, D., Plattner, G.-K., Tignor, M., Allen, S.K. Boschung, J., Midgle, P.M (Eds.), Climate Change 2013: The Physical Science Basis. Contribution of Working Group I to the Fifth Assessment Report of the Intergovernmental Panel on Climate Change. University, Cambridge Press, Cambridge, United Kingdom and New York, NY, USA.

Coope, G.R., Lemdahl, G., Lowe, J.J., Walkling, A., 1998. Temperature gradients in northern Europe during the last glacial-Holocene transition (14-9 14C kyr BP) interpreted from coleopteran assemblages. J. Quat. Sci. 13, 419-433. https://doi. org/10.1002/(SICI)1099-1417(1998090)13:5<419::AID-JQS410>3.0.CO;2-D.

Deluca, T.H., Boisvenue, C., 2012. Boreal forest soil carbon: distribution, function and modelling. For. An Int. J. For. Res. 85, 161-184. https://doi.org/10.1093/forestry/ cps003.

Dodd, J.P., Sharp, Z.D., 2010. A laser fluorination method for oxygen isotope analysis of biogenic silica and a new oxygen isotope calibration of modern diatoms in freshwater environments. Geochim. Cosmochim. Acta 74, 1381-1390. https://doi. org/10.1016/j.gca.2009.11.023.

Dong, J., Wang, Y., Cheng, H., Hardt, B., Edwards, R.L., Xinggong Kong, X., Jiangying Wu, J., Shitao Chen, S., Dianbing Liu, D., Xiuyang Jiang, X., Kan Zhao, K., 2010. A high-resolution stalagmite record of the Holocene East Asian monsoon from Mt Shennongjia, Central China. The Holocene 20, 257-264. https://doi.org/10.1177/ 0959683609350393.

Dykoski, C.A., Edwards, R.L., Cheng, H., Yuan, D., Cai, Y., Zhang, M., Lin, Y., Qing, J., An, Z., Revenaugh, J., Dykoski, C.A., Edwards, R.L., Cheng, H., Yuan, D., Cai, Y., Zhang, M., Lin, Y., Qing, J., An, Z., Revenaugh, J., Dykosko, C., Edwards, R.L., Cheng, H., Yuan, D., Cai, Y., Zhang, M., Lin, Y., Qing, J., An, Z., Revenaugh, J., 2005. A high-resolution, absolute-dated Holocene and deglacial Asian monsoon record from Dongge Cave, China. Earth Planet. Sci. Lett. 233, 71-86. https://doi.org/ 10.1016/j.epsl.2005.01.036.

Fletcher, W.J., Sánchez Goñi, M.F., Allen, J.R.M., Cheddadi, R., Combourieu-Nebout, N., Huntley, B., Lawson, I., Londeix, L., Magri, D., Margari, V., Müller, U.C., Naughton, F., Novenko, E., Roucoux, K., Tzedakis, P.C., 2010. Millennial-scale variability during the last glacial in vegetation records from Europe. Quat. Sci. Rev. 29, 2839-2864. https://doi.org/10.1016/J.QUASCIREV.2009.11.015.

Flower, R., Ryves, D., 2009. Diatom preservation: differential preservation of sedimentary diatoms in two saline lakes. Acta Bot. Croat. 68, 381-399.

Heiri, O., Millet, L., 2005. Reconstruction of late Glacial summer temperatures from chironomid assemblages in Lac Lautrey (Jura, France). J. Quat. Sci. 20, 33-44. https://doi.org/10.1002/jqs.895.

Heiri, O., Tinner, W., Lotter, A.F., 2004. Evidence for cooler European summers during periods of changing meltwater flux to the North Atlantic. Proc. Natl. Acad. Sci. U. S. A. 101, 15285-15288. https://doi.org/10.1073/pnas.0406594101.

Hoek, W.Z., Bos, J.A.A., 2007. Early Holocene climate oscillations-causes and consequences. Quat. Sci. Rev. 26, 1901-1906. https://doi.org/10.1016/j. quascirev.2007.06.008.

Huhne, C., Slingo, J., 2011. Climate: Observations, Projections and Impacts - Russia. Met Office Publication.

Jansen, E., Overpeck, J., Briffa, K.R., Duplessy, J.-C., Joos, F., Masson-Delmotte, V., Olago, D., Otto-Bliesner, B., Richard Peltier, W., Rahmstorf, S., Ramesh, R., Raynaud, D., Rind, D., Solomina, O., Villalba, R., Zhang, D., 2007. Palaeoclimate: 6.5.1 climate forcing and response during the current interglacial. In: Solomon, S.,
Qin, D., Manning, M., Chen, Z., Marquis, M., Averyt, K.B., Tignor, M., Miller, H.L. (Eds.), Climate Change 2007: The Physical Science Basis. Contribution of Working Group I to the Fourth Assessment Report of the Intergovernmental Panel on Climate Change. Cambridge University Press, Cambridge, UK and New York, NY, USA, pp. 459-462.

Juggins, S., 2016. C2 Data Analysis. Network Version 1.7.7. Beta University of Newcastle, Newcastle (2004).

Katsuta, N., Ikeda, H., Shibata, K., Saito-Kokubu, Y., Murakami, T., Tani, Y., Takano, M., Nakamura, T., Tanaka, A., Naito, S., Ochiai, S., Shichi, K., Kawakami, S., Kawai, T., 2018. Hydrological and climate changes in Southeast Siberia over the last 33 kyr. Glob. Planet. Chang. 164, 11-26. https://doi.org/10.1016/j.gloplacha.2018.02.012.

Kilham, P., Kilham, S.S., Hecky, R.E., 1986. Hypothesized resource relationships among African planktonic diatoms. Limnol. Oceanogr. 31, 1169-1181. https://doi.org/ 10.4319/10.1986.31.6.1169.

Kilham, S.S., Kilham, P., 1975. Melosira granulata (Ehr.) Ralfs: morphology and ecology of a cosmopolitan freshwater diatom. SIL Proc. 1922-2010 19, 2716-2721. https:// doi.org/10.1080/03680770.1974.11896368.

Kostrova, S.S., Meyer, H., Chapligin, B., Bezrukova, E.V., Tarasov, P.E., Kuz'min, M.I., 2013a. Reconstruction of the Holocene climate of Transbaikalia: evidence from the oxygen isotope analysis of fossil diatoms from Kotokel Lake. Dokl. Earth Sci. 451, 732-736. https://doi.org/10.1134/S1028334X13070039.

Kostrova, S.S., Meyer, H., Chapligin, B., Kossler, A., Bezrukova, E.V., Tarasov, P.E., 2013b. Holocene oxygen isotope record of diatoms from Lake Kotokel (Southern Siberia, Russia) and its palaeoclimatic implications. Quat. Int. 290-291, 21-34. https://doi.org/10.1016/j.quaint.2012.05.011.

Kostrova, S.S., Meyer, H., Chapligin, B., Tarasov, P.E., Bezrukova, E.V., 2014. The last glacial maximum and late glacial environmental and climate dynamics in the Baikal region inferred from an oxygen isotope record of lacustrine diatom silica. Quat. Int. 348, 25-36. https://doi.org/10.1016/j.quaint.2014.07.034.

Kostrova, S.S., Meyer, H., Tarasov, P.E., Bezrukova, E.V., Chapligin, B., Kossler, A., Pavlova, L.A., Kuzmin, M.I., 2016. Oxygen isotope composition of diatoms from sediments of Lake Kotokel (Buryatia). Russ. Geol. Geophys. 57, 1239-1247. https:// doi.org/10.1016/j.rgg.2016.08.009.

Kostrova, S.S., Meyer, H., Bailey, H.L., Ludikova, A.V., Gromig, R., Kuhn, G., Shibaev, Y. A., Kozachek, A.V., Ekaykin, A.A., Chapligin, B., 2019. Holocene hydrological variability of Lake Ladoga, Northwest Russia, as inferred from diatom oxygen isotopes. Boreas 48, 361-376. https://doi.org/10.1111/bor.12385.

Kostrova, S.S., Meyer, H., Fernandoy, F., Werner, M., Tarasov, P.E., 2020. Moisture origin and stable isotope characteristics of precipitation in Southeast Siberia. Hydrol. Process. 34, 51-67. https://doi.org/10.1002/hyp.13571.

Kozhov, M.M., 1950. Fresh Water of Eastern Siberia. OGIZ Press, Irkutsk.

Krainov, M.A., Bezrukova, E.V., Kerber, E.V., Levina, O.V., Ivanov, E.V., Shchetnikov, A. A., Filinov, I.A., 2017. First results of study of Lake Baunt bottom sediments (northern Transbaikalia). Russ. Geol. Geophys. 58, 1401-1411. https://doi.org/ 10.1016/j.rgg.2017.02.005.

Krainov, M.A., Bezrukova, E.V., Shchetnikov, A.A., Kerber, E.V., 2018. First data on the Gothenburg and Mono Lake excursions in paleomagnetic records from bottom sediments of Lakes of Transbaikalia (exemplified by Baunt Lake). Dokl. Earth Sci. 481, 980-983. https://doi.org/10.1134/S1028334X18080068.

Lane, C.S., Brauer, A., Blockley, S.P.E., Dulski, P., 2013. Volcanic ash reveals timetransgressive abrupt climate change during the Younger Dryas. Geology 41 1251-1254. https://doi.org/10.1130/G34867.1.

Laskar, J., Robutel, P., Joutel, F., Gastineau, M., Correia, A.C.M.M., Levrard, B., 2004 A long-term numerical solution for the insolation quantities of the Earth. Astron. Astrophys. 428, 261-285. https://doi.org/10.1051/0004-6361:20041335.

Leemans, R., Cramer, W.P., 1991. The IIASA Database for Mean Monthly Values of Temperature, Precipitation, and Cloudiness on a Global Terrestrial Grid, Environmental Protection. RR-91-018.

Leng, M.J., Barker, P.A., 2006. A review of the oxygen isotope composition of lacustrine diatom silica for palaeoclimate reconstruction. Earth-Sci. Rev. 75, 5-27. https://doi. org/10.1016/j.earscirev.2005.10.001.

Leng, M.J., Marshall, J.D., 2004. Palaeoclimate interpretation of stable isotope data from lake sediment archives. Quat. Sci. Rev. 23, 811-831. https://doi.org/10.1016/j. quascirev.2003.06.012.

Leng, M.J., Sloane, H.J., 2008. Combined oxygen and silicon isotope analysis of biogenic silica. J. Quat. Sci. 23, 313-319. https://doi.org/10.1002/jqs.1177.

Leng, M.J., Swann, G.E.A., 2010. Stable isotopes from diatom silica. In: Smol, J.P., Stoermer, E.F. (Eds.), The Diatoms: Applications for the Environmental and Earth Sciences. Cambridge University Press, Cambridge, pp. 127-143.

Liu, Z., Zhu, J., Rosenthal, Y., Zhang, X., Otto-Bliesner, B.L., Timmermann, A., Smith, R. S., Lohmann, G., Zheng, W., Elison Timm, O., 2014. The Holocene temperature conundrum. Proc. Natl. Acad. Sci. U. S. A. 111, E3501-E3505. https://doi.org/ 10.1073/pnas.1407229111.

Mackay, A.W., Ryves, D.B., Battarbee, R.W., Flower, R.J., Jewson, D., Rioual, P., Sturm, M., 2005. 1000 years of climate variability in Central Asia: assessing the evidence using Lake Baikal (Russia) diatom assemblages and the application of a diatom-inferred model of snow cover on the lake. Glob. Planet. Chang. 46, 281-297. https://doi.org/10.1016/j.gloplacha.2004.09.021.

Mackay, A.W., Swann, G.E.A., Brewer, T.S., Leng, M.J., Morley, D.W., Piotrowska, N., Rioual, P., White, D., 2011. A reassessment of late glacial - Holocene diatom oxygen isotope record from Lake Baikal using a geochemical mass-balance approach. J. Quat. Sci. 26, 627-634. https://doi.org/10.1002/jqs.1484.

Mackay, A.W., Bezrukova, E.V., Boyle, J.F., Holmes, J.A., Panizzo, V.N., Piotrowska, N., Shchetnikov, A., Shilland, E.M., Tarasov, P., White, D., 2013a. Multiproxy evidence for abrupt climate change impacts on terrestrial and freshwater ecosystems in the 
Ol'khon region of Lake Baikal, Central Asia. Quat. Int. 290-291, 46-56. https://doi. org/10.1016/j.quaint.2012.09.031.

Mackay, A.W., Swann, G.E.a., Fagel, N., Fietz, S., Morley, D., Rioual, P., Tarasov, P., Leng, M.J., 2013b. Hydrological instability during the last Interglacial in Central Asia: a new diatom oxygen isotope record from Lake Baikal. Quat. Sci. Rev. 66, 45-54. https://doi.org/10.1016/j.quascirev.2012.09.025.

Margold, M., Jansen, J.D., Gurinov, A.L., Codilean, A.T., Fink, D., Preusser, F., Reznichenko, N.V., Mifsud, C., 2016. Extensive glaciation in Transbaikalia, Siberia, at the last Glacial Maximum. Quat. Sci. Rev. 132, 161-174. https://doi.org/ 10.1016/j.quascirev.2015.11.018.

Martin, M., Jansson, K.N., 2011. Glacial geomorphology and glacial lakes of central Transbaikalia, Siberia, Russia. J. Maps 7, 18-30. https://doi.org/10.4113/ jom.2011.1132.

Mayewski, P.A., Rohling, E.E., Curt Stager, J., Karlén, W., Maasch, K.A., David Meeker, L., Meyerson, E.A., Gasse, F., van Kreveld, S., Holmgren, K., Lee-Thorp, J., Rosqvist, G., Rack, F., Staubwasser, M., Schneider, R.R., Steig, E.J., 2004. Holocene climate variability. Quat. Res. 62, 243-255. https://doi.org/10.1016/J. YQRES. 2004.07.001.

McManus, J.F., Francois, R., Gherardi, J.-M., Keigwin, L.D., Brown-Leger, S., 2004. Collapse and rapid resumption of Atlantic meridional circulation linked to deglacial climate changes. Nature 428, 834-837. https://doi.org/10.1038/nature02494.

Meyer, H., Schönicke, L., Wand, U., Hubberten, H.W., Friedrichsen, H., 2000. Isotope studies of hydrogen and oxygen in ground ice - experiences with the equilibration technique. Isot. Environ. Health Stud. 36, 133-149. https://doi.org/10.1080/ 10256010008032939.

Meyer, H., Chapligin, B., Hoff, U., Nazarova, L., Diekmann, B., 2015. Oxygen isotope composition of diatoms as late Holocene climate proxy at Two-Yurts Lake, Central Kamchatka, Russia. Glob. Planet. Chang. 134, 118-128. https://doi.org/10.1016/j. gloplacha.2014.04.008.

Moore, M.V., Hampton, S.E., Izmest'eva, L.R., Silow, E.A., Peshkova, E.V., Pavlov, B.K., 2009. Climate change and the World's "Sacred Sea"-Lake Baikal, Siberia. Bioscience 59, 405-417. https://doi.org/10.1525/bio.2009.59.5.8.

Morley, D.W., Leng, M.J., Mackay, A.W., Sloane, H.J., Rioual, P., Battarbee, R.W., 2004. Cleaning of lake sediment samples for diatom oxygen isotope analysis. J. Paleolimnol. 31, 391-401. https://doi.org/10.1023/B: JOPL.0000021854.70714.6b.

Morley, D.W., Leng, M.J., Mackay, A.W., Sloane, H.J., 2005. Late glacial and Holocene environmental change in the Lake Baikal region documented by oxygen isotopes from diatom silica. Glob. Planet. Chang. 46, 221-233. https://doi.org/10.1016/j gloplacha.2004.09.018.

Müller, S., Tarasov, P.E., Hoelzmann, P., Bezrukova, E.V., Kossler, A., Krivonogov, S.K., 2014. Stable vegetation and environmental conditions during the last Glacial maximum: new results from Lake Kotokel (Lake Baikal region, southern Siberia, Russia). Quat. Int. 348, 14-24. https://doi.org/10.1016/J.QUAINT.2013.12.012.

Nenakhov, V.M., Nikitin, A.V., 2007. Structure, magmatism, and Paleozoic tectonic evolution of the Uakit Zone in the context of the formation of the Angara-Vitim batholith in the western Transbaikal region. Geotectonics 41, 114-129. https://doi. org/10.1134/S0016852107020033.

O'Farrell, I., Tell, G., Podlejski, A., 2001. Morphological variability of Aulacoseira granulata (Ehr.) Simonsen (Bacillariophyceae) in the lower Parana River (Argentina). Limnology 2, 65-71. https://doi.org/10.1007/s102010170001.

Osipova, O.P., Osipov, E.Y., 2019. Atmospheric circulation processes and precipitation regime in the Northern part of the Baikal mountain region. Russ. Meteorol. Hydrol. 44, 695-703. https://doi.org/10.3103/S106837391910008X.

Park, T.-W., Jeong, J.-H., Deng, Y., Zhou, R., Cai, M., 2014. Quantitative decomposition of radiative and non-radiative contributions to temperature anomalies related to siberian high variability. Clim. Dyn. 45, 1207-1217. https://doi.org/10.1007/ s00382-014-2371-6.

Pavlova, L.A., Tkachenko, L.L., Goreglyad, A.V., Kuzmin, M.I., 2014. Peculiarities of the diatom valve chemical composition (inorganic components) study by electron probe X-Ray microanalysis. Methods Obj. Chem. Anal. 9, 65-72. https://doi.org/ 10.17721/moca.2014.65-72.

Prokopenko, A.A., Williams, D.F., 2004. Deglacial methane emission signals in the carbon isotopic record of Lake Baikal. Earth Planet. Sci. Lett. 218, 135-147. https:// doi.org/10.1016/S0012-821X(03)00637-X.

Prokopenko, A.A., Williams, D.F., Karabanov, E.B., Khursevich, G.K., 1999. Response of Lake Baikal ecosystem to climate forcing and pCO2 change over the last glacial/ interglacial transition. Earth Planet. Sci. Lett. 172, 239-253. https://doi.org/ 10.1016/S0012-821X(99)00203-4.

Prokopenko, A.A., Williams, D.F., Kuzmin, M.I., Karabanov, E.B., Khursevich, G.K., Peck, J.A., 2002. Muted climate variations in continental Siberia during the midPleistocene epoch. Nature 418, 65-68. https://doi.org/10.1038/nature00886.

Rach, O., Brauer, A., Wilkes, H., Sachse, D., 2014. Delayed hydrological response to Greenland cooling at the onset of the Younger Dryas in Western Europe. Nat. Geosci. 7, 109-112. https://doi.org/10.1038/ngeo2053.

Rasmussen, S.O., Bigler, M., Blockley, S.P.E., Blunier, T., Buchardt, S.L., Clausen, H.B., Cvijanovic, I., Dahl-Jensen, D., Johnsen, S.J., Fischer, H., Gkinis, V., Guillevic, M., Hoek, W.Z., Lowe, J.J., Pedro, J.B., Popp, T., Seierstad, I.K., Steffensen, J.P., Svensson, A.M., Vallelonga, P., Vinther, B.M., Walker, M.J.C., Wheatley, J.J., Winstrup, M., 2014. A stratigraphic framework for abrupt climatic changes during the last Glacial period based on three synchronized Greenland ice-core records: refining and extending the INTIMATE event stratigraphy. Quat. Sci. Rev. 106, 14-28. https://doi.org/10.1016/j.quascirev.2014.09.007.

Reed, S.J.B.B., 2005. Electron Microprobe Analysis and Scanning Electron Microscopy in Geology, Electron Microprobe Analysis and Scanning Electron Microscopy in
Geology. Cambridge University Press. https://doi.org/10.1017/ CBO9780511610561.

Reimer, P., Baillie, M., Bard, E., 2009. IntCal09 and Marine09 radiocarbon age calibration curves, 0-50,000 yeats cal BP. Radiocarbon 51, 1111-1150.

Reimer, P.J., Austin, W.E.N., Bard, E., Bayliss, A., Blackwell, P.G., Bronk Ramsey, C., Butzin, M., Cheng, H., Edwards, R.L., Friedrich, M., Grootes, P.M., Guilderson, T.P., Hajdas, I., Heaton, T.J., Hogg, A.G., Hughen, K.A., Kromer, B., Manning, S.W., Muscheler, R., Palmer, J.G., Pearson, C., van der Plicht, J., Reimer, R.W., Richards, D.A., Scott, E.M., Southon, J.R., Turney, C.S.M., Wacker, L., Adolphi, F., Büntgen, U., Capano, M., Fahrni, S.M., Fogtmann-Schulz, A., Friedrich, R., Köhler, P., Kudsk, S., Miyake, F., Olsen, J., Reinig, F., Sakamoto, M., Sookdeo, A., Talamo, S., 2020. The IntCal20 Northern Hemisphere radiocarbon age calibration curve (0-55 cal kBP). Radiocarbon 00, 1-33. https://doi.org/10.1017/rdc.2020.41.

Renssen, H., Seppä, H., Crosta, X., Goosse, H., Roche, D.M., 2012. Global characterization of the Holocene thermal Maximum. Quat. Sci. Rev. 48, 7-19. https://doi.org/10.1016/J.QUASCIREV.2012.05.022.

Rioual, P., Mackay, A.W., 2005. A diatom record of centennial resolution for the Kazantsevo Interglacial stage in Lake Baikal (Siberia). Glob. Planet. Chang. 46, 199-219. https://doi.org/10.1016/j.gloplacha.2004.08.002.

Rohling, E.J., Pälike, H., 2005. Centennial-scale climate cooling with a sudden cold event around 8,200 years ago. Nature 434, 975-979. https://doi.org/10.1038/ nature03421.

Romanovsky, V.E., Drozdov, D.S., Oberman, N.G., Malkova, G.V., Kholodov, A.L., Marchenko, S.S., Moskalenko, N.G., Sergeev, D.O., Ukraintseva, N.G., Abramov, A. A., Gilichinsky, D.A., Vasiliev, A.A., 2010. Thermal state of permafrost in Russia. Permafr. Periglac. Process. 21, 136-155. https://doi.org/10.1002/ppp.683.

Ryabenko, V.E., Sidorenko, A.B., Florensov, N.A., 1964. Geology of the USSR. V. Xxxv. Buryat Autonomous Soviet Socialist Republic. Part 1. Geological Description, 5. 35. Ed. Nedra, - M.

Rytsk, E.Y., Kovach, V.P., Kovalenko, V.I., Yarmolyuk, V.V., 2007. Structure and evolution of the continental crust in the Baikal Fold Region. Geotectonics 41, 440-464. https://doi.org/10.1134/S0016852107060027.

Ryves, D., Juggins, S., Fritz, S., Battarbee, R., 2001. Experimental diatom dissolution and the quantification of microfossil preservation in sediments. Palaeogeogr. Palaeoclimatol. Palaeoecol. 172, 99-113. https://doi.org/10.1016/S0031-0182(01) 00273-5.

Schenk, F., Väliranta, M., Muschitiello, F., Tarasov, L., Heikkilä, M., Björck, S., Brandefelt, J., Johansson, A.V., Näslund, J.-O., Wohlfarth, B., 2018. Warm summers during the Younger Dryas cold reversal. Nat. Commun. 9, 1634. https://doi.org/ 10.1038/s41467-018-04071-5

Schlolaut, G., Brauer, A., Nakagawa, T., Lamb, H.F., Tyler, J.J., Staff, R.A, Marshall, M. H., Bronk Ramsey, C., Bryant, C.L., Tarasov, P.E., 2017. Evidence for a bi-partition of the Younger Dryas Stadial in East Asia associated with inversed climate characteristics compared to Europe. Sci. Rep. 7, 44983 https://doi.org/10.1038/ srep44983.

Shchetnikov, A.A., 2007. Morphotectonics of lacustrine basins: the Baikal rift zone as an example. Russ. J. Pacific Geol. 1, 120-129. https://doi.org/10.1134/ S1819714007020029.

Shichi, K., Takahara, H., Krivonogov, S.K., Bezrukova, E.V., Kashiwaya, K., Takehara, A., Nakamura, T., 2009. Late Pleistocene and Holocene vegetation and climate records from Lake Kotokel, central Baikal region. Quat. Int. 205, 98-110. https://doi.org/ 10.1016/j.quaint.2009.02.005.

Sigl, M., Winstrup, M., McConnell, J.R., Welten, K.C., Plunkett, G., Ludlow, F., Büntgen, U., Caffee, M., Chellman, N., Dahl-Jensen, D., Fischer, H., Kipfstuhl, S., Kostick, C., Maselli, O.J., Mekhaldi, F., Mulvaney, R., Muscheler, R., Pasteris, D.R., Pilcher, J.R., Salzer, M., Schüpbach, S., Steffensen, J.P., Vinther, B.M., Woodruff, T. E., 2015. Timing and climate forcing of volcanic eruptions for the past 2,500 years. Nature 523, 543-549. https://doi.org/10.1038/nature14565.

Smith, A.C., Leng, M.J., Swann, G.E.A., Barker, P.A., Mackay, A.W., Ryves, D.B., Sloane, H.J., Chenery, S.R.N., Hems, M., 2016. An experiment to assess the effects of diatom dissolution on oxygen isotope ratios. Rapid Commun. Mass Spectrom. 30, 293-300. https://doi.org/10.1002/rcm.7446.

Solotchin, P.A., Sklyarov, E.V., Solotchina, E.P., Zamana, L.V., Sklyarova, O.A., Solotchin, P.A., Sklyarov, E.V., Solotchina, E.P., Zamana, L.V., Sklyarova, O.A., 2015. A new find of Kogarkoite Na3SO4F in Transbaikalia. Dokl. Earth Sci. 462, 643-647. https://doi.org/10.1134/S1028334X15060239.

Stebich, M., Mingram, J., Han, J., Liu, J., 2009. Late Pleistocene spread of (cool-) temperate forests in Northeast China and climate changes synchronous with the North Atlantic region. Glob. Planet. Chang. 65, 56-70. https://doi.org/10.1016/j. gloplacha.2008.10.010.

Steffensen, J.P., Andersen, K.K., Bigler, M., Clausen, H.B., Dahl-Jensen, D., Fischer, H., Goto-Azuma, K., Hansson, M., Johnsen, S.J., Jouzel, J., Masson-Delmotte, V., Popp, T., Rasmussen, S.O., Röthlisberger, R., Ruth, U., Stauffer, B., SiggaardAndersen, M.-L., Sveinbjörnsdóttir, Á.E., Svensson, A., White, J.W.C., Sveinbjörnsdóttir, A.E., Svensson, A., White, J.W.C., 2008. High-resolution Greenland ice core data show abrupt climate change happens in few years. Science 321, 680-684. https://doi.org/10.1126/science.1157707.

Stokes, C.R., Shahgedanova, M., Evans, I.S., Popovnin, V.V., 2013. Accelerated loss of alpine glaciers in the Kodar Mountains, South-Eastern Siberia. Glob. Planet. Chang. 101, 82-96. https://doi.org/10.1016/j.gloplacha.2012.12.010.

Swann, G.E.A., Leng, M.J., 2009. A review of diatom $\delta 180$ in palaeoceanography. Quat. Sci. Rev. 28, 384-398. https://doi.org/10.1016/j.quascirev.2008.11.002.

Swann, G.E.A., Patwardhan, S.V., 2011. Application of Fourier Transform infrared Spectroscopy (FTIR) for assessing biogenic silica sample purity in geochemical analyses and palaeoenvironmental research. Clim. Past 7, 65-74. https://doi.org/ 10.5194/cp-7-65-2011. 
Swann, G.E.A., Leng, M.J., Sloane, H.J., Maslin, M.A., Onodera, J., 2007. Diatom oxygen isotopes: evidence of a species effect in the sediment record. Geochem. Geophys. Geosyst. 8, Q06012 https://doi.org/10.1029/2006GC001535.

Swann, G.E.A., Leng, M.J., Juschus, O., Melles, M., Brigham-Grette, J., Sloane, H.J., 2010. A combined oxygen and silicon diatom isotope record of late Quaternary change in Lake El'gygytgyn, North East Siberia. Quat. Sci. Rev. 29, 774-786. https:// doi.org/10.1016/j.quascirev.2009.11.024.

Swann, G.E.A., Mackay, A.W., Vologina, E., Jones, M.D., Panizzo, V.N., Leng, M.J., Sloane, H.J., Snelling, A.M., Sturm, M., 2018. Lake Baikal isotope records of Holocene Central Asian precipitation. Quat. Sci. Rev. 189, 210-222. https://doi.org/ 10.1016/J.QUASCIREV.2018.04.013.

Tarasov, P., Bezrukova, E., Karabanov, E., Nakagawa, T., Wagner, M., Kulagina, N., Letunova, P., Abzaeva, A., Granoszewski, W., Riedel, F., 2007. Vegetation and climate dynamics during the Holocene and Eemian interglacials derived from Lake Baikal pollen records. Palaeogeogr. Palaeoclimatol. Palaeoecol. 252, 440-457. https://doi.org/10.1016/J.PALAEO.2007.05.002.

Tarasov, P.E., Bezrukova, E.V., Krivonogov, S.K., 2009. Late Glacial and Holocene changes in vegetation cover and climate in southern Siberia derived from a $15 \mathrm{kyr}$ long pollen record from Lake Kotokel. Clim. Past Discuss. 5, 127-151. https://doi. org/10.5194/cpd-5-127-2009.

Tchebakova, N.M., Parfenova, E., Soja, A.J., 2009. The effects of climate, permafrost and fire on vegetation change in Siberia in a changing climate. Environ. Res. Lett. 4 045013 https://doi.org/10.1088/1748-9326/4/4/045013.

Tchebakova, N.M., Parfenova, E.I., Soja, A.J., 2011. Climate change and climate-induced hot spots in forest shifts in Central Siberia from observed data. Reg. Environ. Chang. 11, 817-827. https://doi.org/10.1007/s10113-011-0210-4.

Teller, J.T., Leverington, D.W., Mann, J.D., 2002. Freshwater outbursts to the oceans from glacial Lake Agassiz and their role in climate change during the last deglaciation. Quat. Sci. Rev. 21, 879-887. https://doi.org/10.1016/S0277-3791(01) 00145-7.

Terzer, S., Wassenaar, L.I., Araguás-Araguás, L.J., Aggarwal, P.K., 2013. Global isoscapes for delta $18 \mathrm{O}$ and delta2 $\mathrm{H}$ in precipitation: improved prediction using regionalized climatic regression models. Hydrol. Earth Syst. Sci. Discuss. 10, 7351-7393. https:// doi.org/10.5194/hessd-10-7351-2013.

Tingley, M.P., Huybers, P., 2013. Recent temperature extremes at high northern latitudes unprecedented in the past 600 years. Nature 496, 201-205. https://doi.org/ 10.1038/nature11969.

Tsygankov, A.A., Matukov, D.I., Berezhnaya, N.G., Larionov, A.N., Posokhov, V.F., Tsyrenov, B.T., Khromov, A.A., Sergeev, S.A., 2007. Late Paleozoic granitoids of
Western Transbaikalia: magma sources and stages of formation. Russ. Geol. Geophys. 48, 120-140. https://doi.org/10.1016/J.RGG.2006.12.011.

Tubi, A., Dayan, U., 2013. The Siberian High: teleconnections, extremes and association with the Icelandic Low. Int. J. Climatol. 33, 1357-1366. https://doi.org/10.1002/ joc. 3517.

Ufimtsev, G.F., Shchetnikov, A.A., Filinov, I.A., 2009. Neotectonic inversions in the Baikal Rift system. Russ. Geol. Geophys. 50, 618-627. https://doi.org/10.1016/j. rgg.2008.12.006.

van Hardenbroek, M., Chakraborty, A., Davies, K.L., Harding, P., Heiri, O., Henderson, A. C.G., Holmes, J.A., Lasher, G.E., Leng, M.J., Panizzo, V.N., Roberts, L., Schilder, J., Trueman, C.N., Wooller, M.J., 2018. The stable isotope composition of organic and inorganic fossils in lake sediment records: current understanding, challenges, and future directions. Quat. Sci. Rev. 196, 154-176. https://doi.org/10.1016/J. QUASCIREV.2018.08.003.

Wang, Y.J., Cheng, H., Edwards, R.L., An, Z.S., Wu, J.Y., Shen, C.C., Dorale, J.A., 2001. A high-resolution absolute-dated late Pleistocene Monsoon record from Hulu Cave, China. Science 294, 2345-2348. https://doi.org/10.1126/science.1064618.

Wanner, H., Solomina, O., Grosjean, M., Ritz, S.P., Jetel, M., 2011. Structure and origin of Holocene cold events. Quat. Sci. Rev. 30, 3109-3123. https://doi.org/10.1016/j. quascirev.2011.07.010.

Weninger, B., Jöris, O., 2008. A 14C age calibration curve for the last $60 \mathrm{ka}$ : the Greenland-Hulu U/Th timescale and its impact on understanding the Middle to Upper Paleolithic transition in Western Eurasia. J. Hum. Evol. 55, 772-781. https:// doi.org/10.1016/j.jhevol.2008.08.017.

Williams, D.F., Peck, J., Karabanov, E.B., Prokopenko, A.A., Kravchinsky, V., King, J., Kuzmin, M.I., 1997. Lake Baikal record of continental climate response to orbital insolation during the past 5 million years. Science 278, 1114-1117. https://doi.org/ 10.1126/science.278.5340.1114.

Williams, J.W., Blois, J.L., Shuman, B.N., 2011. Extrinsic and intrinsic forcing of abrupt ecological change: case studies from the late quaternary. J. Ecol. 99, 664-677. https://doi.org/10.1111/j.1365-2745.2011.01810.x.

Wilson, K.E., Leng, M.J., Mackay, A.W., 2014. The use of multivariate statistics to resolve multiple contamination signals in the oxygen isotope analysis of biogenic silica. J. Quat. Sci. 29, 641-649. https://doi.org/10.1002/jqs.2729.

Yakhnenko, V.M., Mamontov, A.M., Luczynski, M., 2008. East-Siberian coregonid fishes: their occurrence, evolution and present status. Environ. Biotechnol. 4, 41-53.

Zhang, W., Yan, H., Dodson, J., Cheng, P., Liu, C., Li, J., Lu, F., Zhou, W., An, Z., 2018. The $9.2 \mathrm{ka}$ event in Asian summer monsoon area: the strongest millennial scale collapse of the monsoon during the Holocene. Clim. Dyn. 50, 2767-2782. https:// doi.org/10.1007/s00382-017-3770-2. 